Journal of Nepal Geological Society, 2019, vol. 59, pp. 19-37

DOI: https://doi.org/103126/jngs.v59i0.24983

\title{
Geomorphometric properties and variability of sediment delivery ratio and specific sediment yield among sub-basins of the Karra River, Hetauda, central Nepal Sub-Himalaya
}

\author{
*Naresh Kazi Tamrakar and Binod Karki \\ Central Department of Geology, Tribhuvan University, Kirtipur, Kathmandu, Nepal \\ *Corresponding author: nktam777@yahoo.com
}

\begin{abstract}
Geomorphometric properties of watershed-scale are often calculated to characterize drainage basins morphology for evaluating their geomorphic status of basin development. More recently these properties have widely been applied in inferring the sediment delivery ratio and sediment yields of the basin to estimate and know sediment erosion status of drainage basin with the help of morphometric data. In fact, sediment delivery ratio (SDR) and specific sediment yield (SSY) of the basins depend not only on watershed properties but also indirectly on other factors such as climate, hydrology, landuse and geology, which can be of low variation for a smallwatershed. The aims of the present study were to compute some of the geomorphometric parameters of the Karra River Basin (KRB), located in Hetauda, Makawanpur District, Central Nepal, to compare some of these among the sub-basins with varying geology, to use some of parameters in estimating sub-basin-wide SDR and SSY using empirical equations and to infer geomorphic development and erosion status of the basin. Based on hypsometric analysis, the southern sub-basins with mainly gravelly terrain are mostly of mature to unstable phase, whereas the northern sub-basins with bedrocks of the Lower and the Middle Siwalik Subgroups are of Monadnock phase to mature stage of basin development. Sediment delivery ratio (SDR) and specific sediment yield (SSY) estimated for the southern sub-basins of the KRB are relatively lower compared to those estimated for the northern sub-basins. Considering the geology of the KRB and hypsometric integral, although the SDR and SSY of the southern sub-basins are lower compared to the northern sub-basins, the southern sub-basins are vulnerable to erosion because of their unstable geomorphic development stage and pervasive distribution of unconsolidated weak sediments having high erodibility.
\end{abstract}

Keywords: Morphometric analysis, Hypsometric integral, Sediment delivery ratio, Specific sediment yield, Hetauda

Paper Received: 10 Apr 2019

Paper Accepted: 1 Jun 2019

\section{INTRODUCTION}

Morphometric characteristics of watershed-scale not only provide information on basin development stage (Horton, 1945; Strahler, 1952; Leopold and Maddock, 1953) but also provide quantitative measurements and description on the drainage to characterize basin (Strahler, 1964; Singh, 1992). Morphometric analysis of drainage are generally carried out for generating quantitative data on basin network, basin geometry, relief aspects and hypsometric curves and hypsometric integral (Langbein et al., 1947; Strahler, 1952; Strahler, 1957; Singh et al., 1977; Singh and Sharma, 1994; Verstraeten and Poesen, 2001; Singh et al. 2008; Pareta and Pareta, 2011; Nguyen and Chen, 2018). There have been wide concerns on sediment los of the basins and their morphometric parameters (Schumm, 1954; Maner and Barnes, 1953; Glymph, 1954; Maner, 1958; Roehl, 1962). Maner and Barnes (1953) defined sediment delivery rate as percent of annual sheet erosion as sediment. Sediment delivery ratio (SDR) was defined as ratio of the sediment yield and gross erosion during a given time interval (Roehl, 1962; Walling, 1983). Schumm (1954) and Hadley and Schumm (1961) found significant regression between sediment loss per unit area and relief ratio of the basin. Maner (1958) found strong correlation between relief ratio and SDR. Roehl (1962) developed equation for sediment delivery rate in terms of drainage area, average stream length, relief ratio and weighted mean bifurcation ratio. Nguyen and Chen (2018) estimated SDR by slope and relief ratio and compared two similar empirical equations and concluded that the relief ratio equation predicted SDR better than the slope equation.

Singh and Sharma (1994) attempted to establish relationships of morphometric characteristics with sediment yield. Sediment yield and SDR are commonly related to drainage asin area (Roehl, 1962; Walling, 1983; USDA-NRCS, 1983; Ichim, 1990; Wasson, 1994, Dedkov, 2004; Dumitriu, 2014). Ichim (1990) concluded that SDR decreased notably with an increase of drainage network orders and the relationship depended on erodibility of rock and hydrology of the drainage basin. Sediment yield was correlated with morphometric parameters by several authors (Glymph, 1954; Singh and Sharma, 1994; de Boer and Crosby, 1996; Dedkov, 2004; de Vente et al., 2011) who found positive correlation between sediment yield and drainage basin area, and this relationship was described by the power function. Positive correlation between annual sediment yield and drainage area was found by de Boer and Crosby 


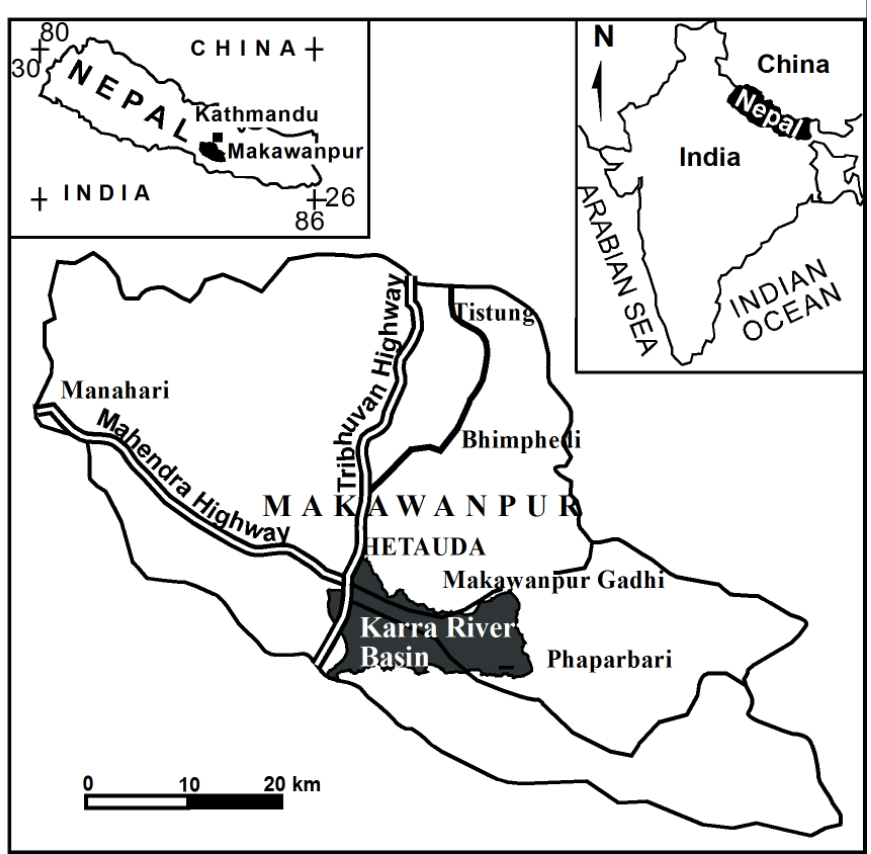

Fig. 1: Location map of the study area (Karra River Basin)

(1996). However, this relation was significantly affected by drainage basin scale. Singh and Sharma (1994) emphasized that the constant of channel maintenance and relief ratio were highly correlated with sediment yield. Dedkov (2004) pointed out that relationship between sediment yield and drainage area depends on landuse and degree of disturbance of the basin. de Vente et al. (2011) found high degree of correlation of drainage area, perimeter, stream length and relief ratio with specific sediment yield. Didone et al (2014) estimated sediment delivery ratio and sediment yield by using equation for various scenarios of cultivation in catchment. Verstraeten and Poesen (2001) applied multiple regression model to predict total sediment yield from the catchment. Versraeten and Poesen (2001) used hypsometric integral to sediment yield prediction model. Hypsometric analysis of the drainage basin has been considered as a powerful tool for drawing inference about erosion status of the drainage basin. This relation of horizontal cross-sectional drainage basin area to elevation was developed by Longbein and others (1947). Hurtrez et al. (1999) found positive correlation between hypsometric integral and upliftment rate of the basin. Singh et al. (2008) estimated hypsometric integral and showed their relevance to erosion status of drainage basins. More recently Mahmood et al. (2016) used hypsometric analysis in concluding erosion status of the drainage basin.

SDR and specific sediment yield (SSY) of the basins provide information on status of erosion of the drainage basin. SDR and SSY depend not only on watershed properties but also indirectly on other factors such as climate, hydrology, landuse and geology (Verstraeten and Poesen, 2001; de Vente et al., 2011; Dumitriu, 2014). When the drainage basin is small having low variation among the factors mentioned, estimation of SDR and SSY from morphometric parameters alone would be helpful in providing relative figures of SDR and SSY. Therefore, the aims of this study are to compute some of the geomorphometric parameters of the Karra River Basin (KRB), to compare some of these with geology, to use some of parameters in estimating sub-basinwide SDR and SSY using empirical equations and to infer geomorphic development and erosion status of the basin.

\section{METHODOLOGY}

Topographic sheets of 1:25,000 scale was used for quantitative morphometric analysis assisted by Scion Image Analyser. The morphometric properties were categorized into linear, relief, and aerial aspects and are described in Table 1.

The hypsometric analysis was carried out by firstly finding relative height and relative area of the basin defined by successive contours. Relative height was calculated from the ratio of height of the contour from the base of the sub-basin to the maximum basin elevation upto remote point on catchment divide. The relative area was obtained from the ratio of area above a particular contour to the total basin area. The relative height vs. relative area from higher elevation contours to the outlet of the basin were plotted to obtain a hypsometric curve, the shape of which may vary as (1) extremely S-type convex down, (2) gently convex down S-type, and concave up type, respectively representing young stage (non-equilibrium), mature stage (equilibrium), and Monadnock stage (stable). Hypsometric integral (HI) can be derived from the percent area lying under the hypsometric curve (Strahler, 1952). In present study, HI was obtained from elevation-relief ratio as indicated in Table 1. Hypsometric integral (HI) values for each of the sub-basins were calculated using ratio of Pike and Wilson (1971)'s equation:

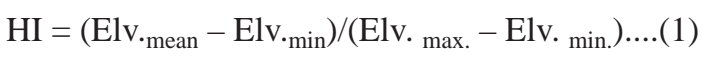

where, Elv. mean is the weighted mean elevation of the sub-basin from the identifiable contours of the sub-basin. Elv. mean was obtained using the equation (Horton, 1932):

$$
\text { Elv. mean }=\left(\operatorname{SUM}\left(\mathrm{a}_{(\mathrm{h} 1+\mathrm{h} 2)} / 2\right) / \mathrm{A}\right.
$$

where, $\mathrm{a}$ is the area between two contour elevations, $\mathrm{h} 1$ and $\mathrm{h} 2$ and $\mathrm{A}$ is the basin area.

The calculated HI indicates three stages of the basin: (1) HI> 0.5 representing basin with deep incision and slight erosion from active tectonics, (2) $0.4<\mathrm{HI}<0.5$ indicate basins with approximate equilibrium and an intermediate stage of incision and erosion from recent active tectonic, and (3) $\mathrm{HI}<$ 0.4 indicating basins with low relief and severe erosion (El. Hamdouni, 2007).

The Karra River Basin (KRB) was mapped for its geology in 1:25,000-scale to delineate geological boundaries and distinguish spatial distribution of geological units in the KRB.

According to Maner (1958) and Renfro (1975), SDR is correlated with relief length ratio. However, the equations 
Table 1: Morphometric parameters computed

\begin{tabular}{|c|c|c|c|}
\hline Parameters & Formula & Description & Reference \\
\hline \multicolumn{4}{|l|}{ Linear Aspects } \\
\hline Stream order $(\mathrm{u})$ & \multicolumn{2}{|l|}{ Hierarchical rank } & Strahler (1952) \\
\hline Bifurcation ratio $(\mathrm{Rb})$ & $\mathrm{Rb}=\mathrm{Nu} / \mathrm{Nu}+1$ & $\begin{array}{l}\mathrm{Nu}=\text { tot. no. of stream segments of order } u \\
\mathrm{Nu}+1=\text { tot. no. of stream segments of order next } \\
\text { higher order }(u+1)\end{array}$ & Strahler (1964) \\
\hline Perimeter $(\mathrm{P})$ & & $\begin{array}{l}\text { Length of circumference enclosing the drainage } \\
\text { basin }\end{array}$ & Schumm (1956) \\
\hline Basin length $(\mathrm{Lb})$ & & $\begin{array}{l}\text { Length from outlet to the maximum Elv. Point at } \\
\text { the watershed divide }\end{array}$ & Schumm (1956) \\
\hline \multicolumn{4}{|l|}{ Relief Aspects } \\
\hline Basin relief $(\mathrm{Bh})$ & $\mathrm{Bh}=\mathrm{H}-\mathrm{h}$ & $\mathrm{H}=\max . \mathrm{Elv}$. and $\mathrm{h}=\min . \mathrm{Elv}$ & $\begin{array}{l}\text { Hadley and } \\
\text { Schumm (1961) } \\
\text { Strahler (1952) }\end{array}$ \\
\hline Relative relief ( $\mathrm{Rr}$ ) & $\mathrm{Rr}=100 *(\mathrm{H}-\mathrm{h}) / \mathrm{P}$ & & Melton (1957) \\
\hline Relief ratio (Rh) & $\mathrm{Rh}=(\mathrm{H}-\mathrm{h}) / \mathrm{Lb}$ & Ratio of basin relief to basin length & Schumm (1956) \\
\hline \multicolumn{4}{|l|}{ Areal Aspects } \\
\hline Basin area $(A)$ & & & Schumm (956) \\
\hline Stream frequency & \multicolumn{3}{|l|}{$\mathrm{Nu} / \mathrm{A}$} \\
\hline Circularity index (Rc) & \multicolumn{2}{|c|}{$\begin{array}{l}\mathrm{Rc}=4 \pi \mathrm{A} / \mathrm{P}^{\wedge} 2 \\
\mathrm{HI}=(\mathrm{Fly} \text { mean }-\mathrm{Fly} \min ) /(\mathrm{Fly} \max -\mathrm{Fly} \mathrm{min})\end{array}$} & Miller (1953) \\
\hline Hysometric integral (HI) & \multicolumn{2}{|c|}{$\mathrm{HI}=($ Elv.mean - Elv. min. $) /($ Elv. $\max -$ Elv. min. $)$} & $\begin{array}{l}\text { Pike and Wilson } \\
\text { (1971) }\end{array}$ \\
\hline
\end{tabular}

developed by them were for local regions and may not be applicable to other regions. USDA-NRCS (1983) developed an equation considering drainage basins from various regions to predict SDR. The following equation after USDA-NRCS (1983) was used to estimate SDR:

$$
\operatorname{SDR}=0.418 \mathrm{~A}^{-0.135}-0.127
$$

Where, A is drainage basin area in sq. miles.

Specific sediment yield (SSY), which is a sediment yield per hectare per year, was estimated after Verstraeten and Poesen (2001) using the following equations:

$$
\operatorname{InSSY}=3.72-0.72 * \operatorname{In} \mathrm{A}-0.84 * \operatorname{InHI}+0.11 * \operatorname{InDL} .
$$

Where, $\mathrm{A}=$ drainage basin area in hectare, $\mathrm{HI}=$ hypsometric integral and $\mathrm{DL}=$ drainage length in $\mathrm{m}$.

\section{TOPOGRAPHY AND DRAINAGE NETWORK}

The northern ridge at Dhungegadhi forms the highest elevation (1322 m) of the KRB and the least lying elevation is $430 \mathrm{~m}$ at the outlet of the basin (Fig. 2). A prominent ridge extends along Kusumdada-Dhungegadhi in the northern part of the KRB and along the Churiya Range in the southern part of the KRB. The low-lying areas extend approximately NWWSEE around the Karra River. The northern ridges have high relief and rugged topography compared to the southern ridges which exhibits badland topography, incised and eroded by many deep and tortuous gullies.

The Karra River is the fifth order axial drainage system developed subparallel to the hinge of the anticline (Fig. 2). It has several contributaries from the lateral part showing trellis pattern. But the upstream drainage systems of each of the contributaries exhibit dendritic pattern. Some of the major contributaries of the Karra River are Kahar Khahare, Agrathe Khahare, Chisapani Khahare, Gauritar Khahare, Trishuli Khola, Sukaura Khola, Ghatte Khola, Thulodamar Khola and the Phurkechaur Khahare from the south, and Bhedaha Khola, Karra Khola, Tamaune Khola and Barauli Khola from the north.

\section{GEOLOGY OF KARRA RIVER BASIN}

The Siwalik Group of the Sub-Himalaya can be divided into three lithostratigraphic units, the Lower Siwalik Subgroup, the Middle Siwalik Subgroup and the Upper Siwalik Subgroup throughout Nepal (Hagen, 1969; Itihara et al., 1972; West and Munthe, 1981; Schelling, 1991), despite it was mapped using local names for litho-units by several researchers (Sah et al., 1994; Ulak and Nakayama, 1998; Tamrakar et al., 2003; Syangbo and Tamrakar, 2013). The Siwalik Group represents the Late Tertiary continental molasses deposited within the southern foreland basin and uplift during the rising of the Himalaya. The lower part of the Siwalik succession contains fine- to medium-grained siliciclastic rocks and the upper part contains increasingly coarse-grained siliciclastic rocks such as conglomerate. The age of the Siwalik Group ranges from Middle Miocene to early Pleistocene in Hetauda-Bakiya River region (>11 Ma to <1Ma (Gautam and Rösler, 1999)).

The Siwalik succession in the KRB spans for about 6-9 $\mathrm{km} \mathrm{N-S}$ and 17-18 E-W, and it shows overall coarsening up sequence. The three-fold subdivision of the Siwalik Group 


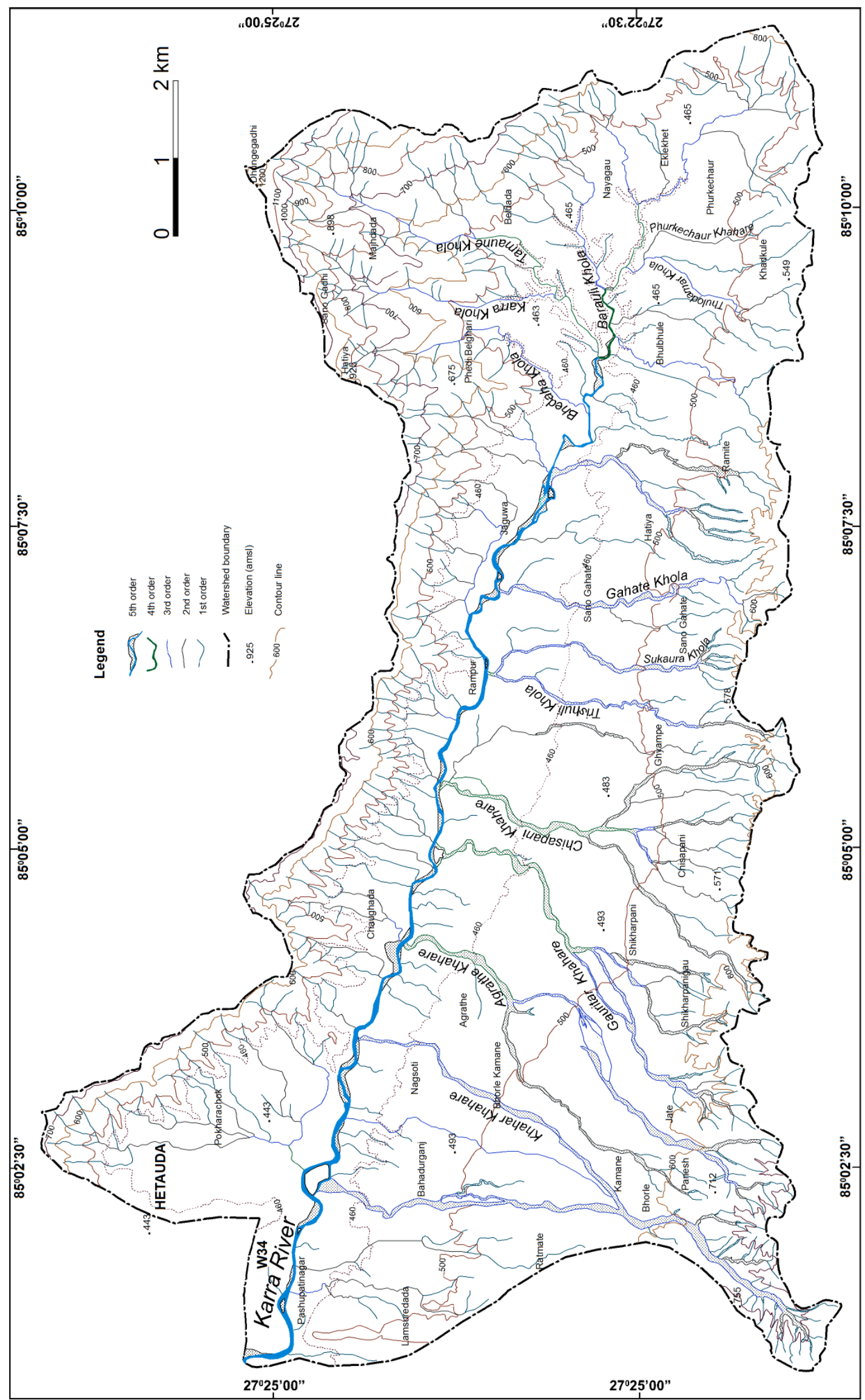

| 
applies to the geology of the KRB. The Siwalik Group is therefore subdivided into the Lower Siwalik Subgroup, Middle Siwalik Subgroup and the Upper Siwalik Subgroup. The group is exposed mainly in the peripheral of the KRB and the central portion has been covered by the Quaternary alluvial deposits (Fig. 3).

The Upper Siwalik Subgroup is thrust over by the Lower Siwalik Subgroup along the Main Dun Thrust (Schelling, 1991; Kimura, 1994) in the southwestern part of the KRB. The MDT thrust divides the Siwalik Group into two belts, the north belt and south belt, and dips towards NE direction. The main indicator of the MDT is the presence of brecciated zone, and an older succession overlying the younger succession with distinct lithological contrast. The strata of the Lower Siwalik Subgroup at Ratomate are folded with their hinge approximately parallel to E-W direction, into a syncline (Ratomate Syncline) and an anticline (Karra River Anticline (Kimura, 1994)) with its hinge extending subparallel to the Karra River (Fig. 3b). The southern limb of the Ratomate syncline is exposed at Bhorle, Jate and Sikharpanigau, whereas its northern limb is exposed at the Lamsuredada near Pashupatinagar and between Nagsoti and Kamane (Fig. 3). This northern limb of the Ratomate Syncline is the southern limb of the Karra River Anticline. The northern limb of the Karra River Anticline is exposed at Kusumdada, Chaugada and Chundada. Both syncline and anticline are of open type as seen across the Y-Z and the A-B cross-sections (Fig. 3b), and become gentle folds towards the east as seen across the C-D cross-section.

\section{Lower Siwalik Subgroup}

It is characterized by fine- to medium-grained, light grey calcareous sandstone alternating with variegated mudstone (purple, brown, yellow orange), greenish grey siltstone and occasionally carbonate and carbonaceous beds. At the left bank of the Khahar Khahare south of Bhorle, the lithology appears to be alternating cycles of variegated mudstone, greenish grey siltstone, purple shale and calcareous sandstones in the lower part and greenish grey calcareous siltstone, fine-grained calcareous sandstone in the middle and the weathered light grey siltstone and fine-grained brownish grey calcareous sandstone in the upper part (Fig. 4). The rocks of this formation dip in to both NE-SW directions frequently showing minor small-scale plunging folds to the large-scale synclines and anticlines, which are observed at Ratomate and Lamsuredanda regions, but are generally concealed below the Quaternary Alluvial Deposit in the central and eastern regions of the KRB. The contact between Lower Siwalik Subgroup and the Middle Siwalik Subgroup is transitional, and is exposed at Chaukitol at the left bank of Rapati River and at the Kanti Rajpath near the Sikharkateri Village.

\section{Middle Siwalik Subgroup}

This succession consists of medium to coarse-grained, thick-bedded calcareous 'salt-and-pepper' sandstones alternating with greenish grey mudstone, calcareous bluish grey mud shale, and occasionally pebbly sandstone and conglomerate. Dominance of sandstone over mudstone is distinct. This unit is well exposed at Kusumdada-Sikharkateri ridge, and along the Kanti Rajpath at different localities like Sikharkateri, Hatiya and Sano Gadhi. On the uphill side of the Kanti Rajpath, at the Sikharkateri Village, alternating strata of siltstone, mudstone and mediumgrained calcareous 'salt-and-pepper' sandstones of the Middle Siwalik Subgroup are exposed (Fig. 5). The rocks of the Middle Siwalik Subgroup generally extend towards NW-SE direction, but at places are folded forming plunging syncline and anticline of local scale.

\section{Upper Siwalik Subgroup}

This lithounit is well exposed along the upstream portions of the Khahar Khahare, Agrathe Khahare, Gauritar Khahare, Chisapani Khahare and the Trishuli Khola. The lithology of the Upper Siwalik Subgroup in the KRB is dominantly of matrixsupported, loosely consolidated pale yellow to reddish brown pebble cobble conglomerate (Fig. 6) with subrounded to subangular clasts mostly of which are of quartzite and subordinately of sandstone, phyllite, slates and granite. Few fine-grained grey sandstone and yellowish grey to orange mudstone beds of 1 to $2 \mathrm{~m}$ occasionally intercalate with conglomerates. Dipping of this sequence is generally in NE direction.

\section{Quaternary Alluvial Deposits}

The central and most of the southern portions of the KRB are occupied by the Quaternary Alluvial Deposits of unconsolidated deposits, which unconformably overlie the Siwalik Group. These unconsolidated, coarse to fine deposits consist of sediments derived from the rivers that originate within the KRB, from the surrounding Siwalik Hills, except in the depositional site of the Rapti River (Duvadi, 2006). The Quaternary Alluvial Deposits can be distinguished into the Upper, the Middle and the Lower morpholithologic zones.

Upper Zone: The relative height of the Upper Zone is 45-90 $\mathrm{m}$ at the western part of the study area and it decreases towards the eastern part. The zone comprises of alternating beds of thick, moderately sorted gravel and thin silt-sand. The clasts are composed of quartzite, metasandstone, sandstone and rarely slate. The top of the deposit is severally weathered and changed to red clay. The Upper Zone was formed as alluvial fans from the lateral drainage system.

Middle Zones: The relative height of the Middle Zone is $15-45 \mathrm{~m}$ from the river bed. At Gauritar, the east-central part of the KRB, the middle zone is mostly covered with younger alluvial deposits. The zone is characterized by interfingered beds of gravel and silty sand. The gravelly bed consists of well rounded, quartzite, metasandstone, sandstone and siltstone derived from the Upper Siwalik Subgroup of the Churiya Range located in the southern part of the KRB. 


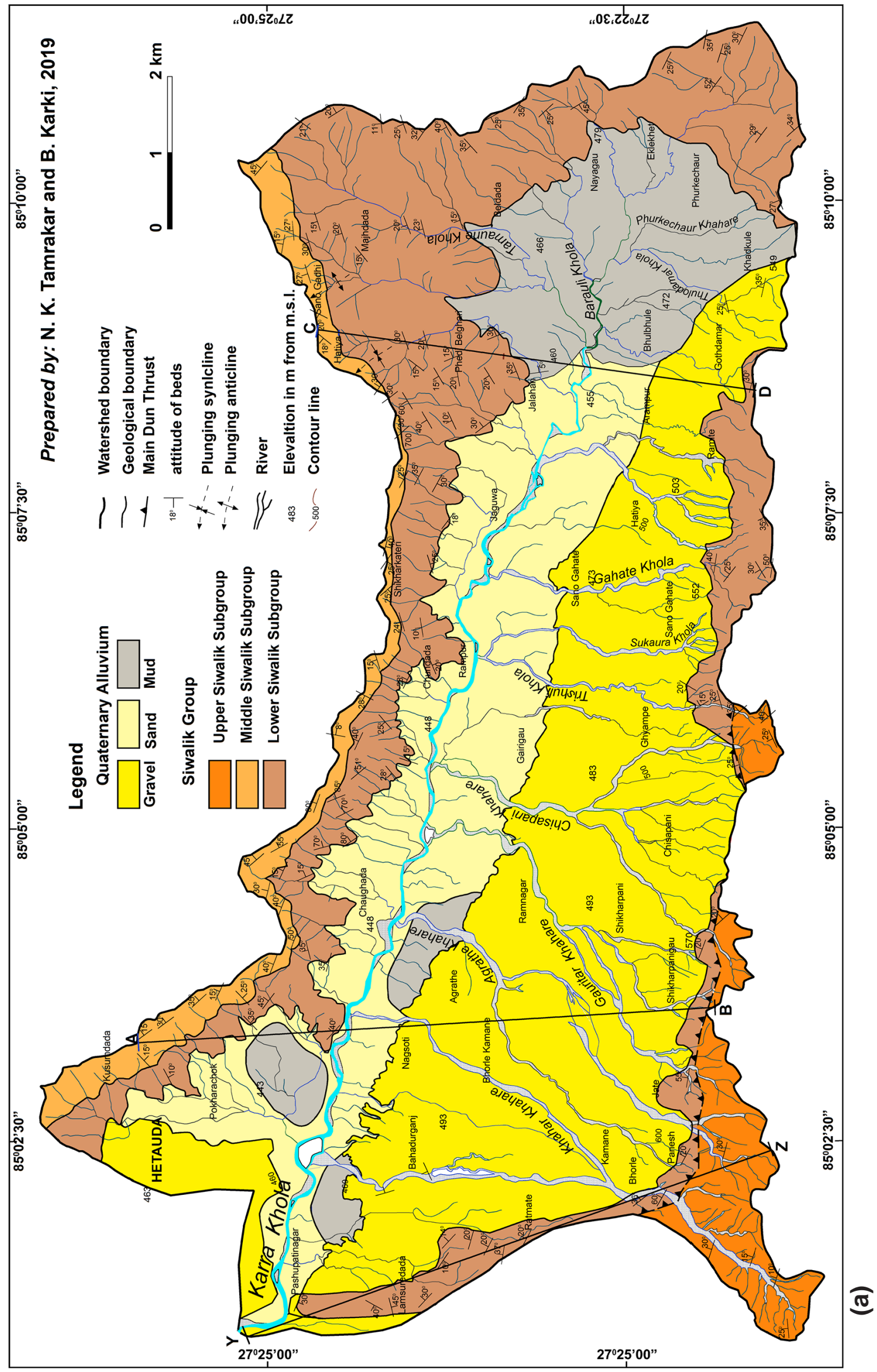



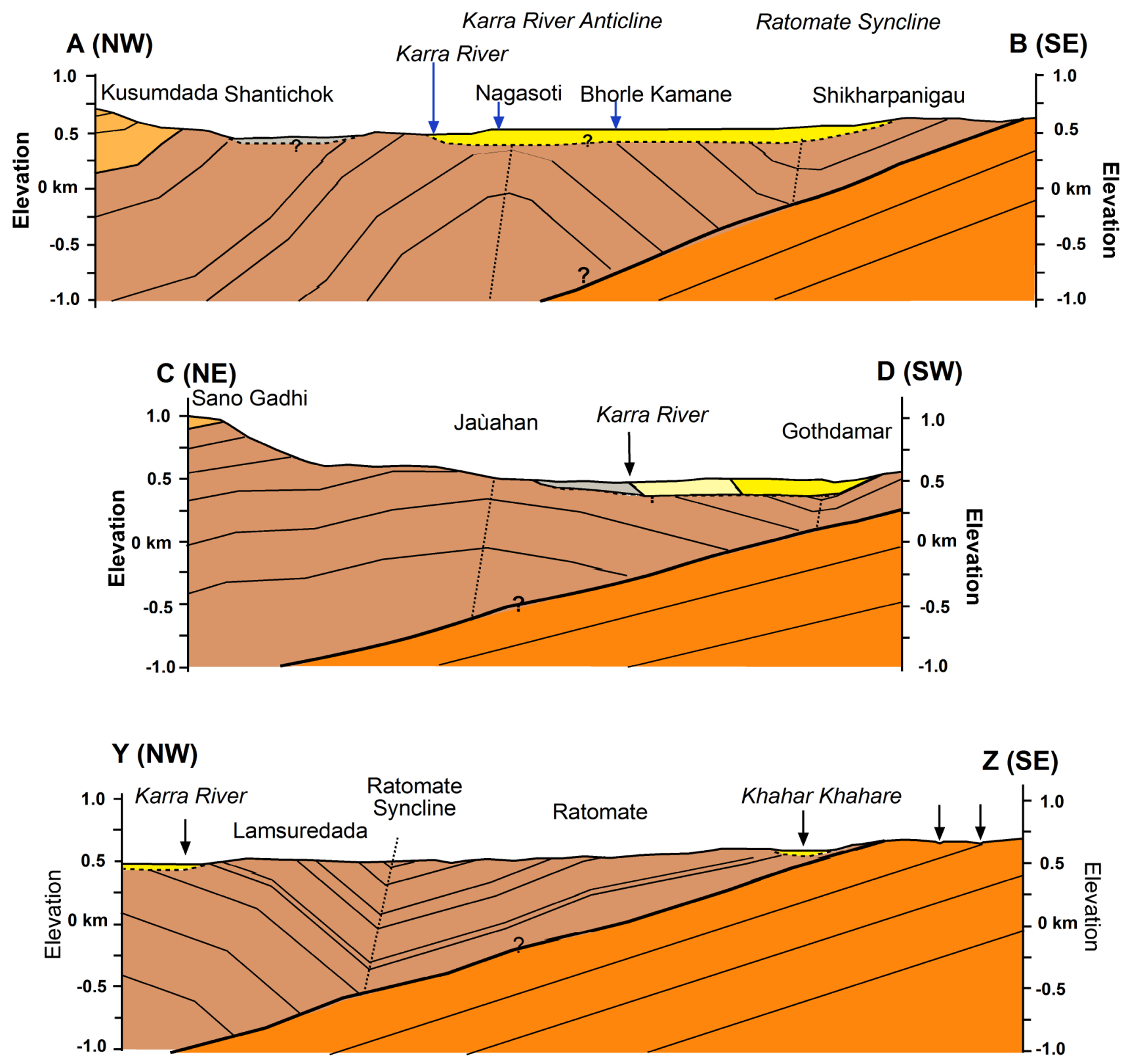

(b)

Fig. 3: (a) Geological map of the Karra River Basin and (b) Geological cross-sections

Lower Zones: The Lower Zone lies at less than $15 \mathrm{~m}$ relative height from the Karra River and consists of mostly of Karra River floodplain and channel sediments transported along the axial drainage. This zone is dominated by the fine-grained sediments such as muds and sands. Often carbonaceous mud and lignite beds occur at this zone as observed north of Agrathe and east of Pashupatinagar at the channel and banks of the Karra River. The zone is slightly dissected by fans formed by the lateral tributaries of the Karra River. Compared to the Upper and the Middle zones, grain size of sediments is finer and there is absence of red weathering crust on the surface.

\section{MORPHOMETRIC PROPERTIES}

\section{Linear Aspects}

Stream order (u): It is a hierarchical order of streams in a drainage basin as computed after Strahler $(1952,1957)$. The mainstem Karra River contributing to the Rapati Nadi is the fifth order stream (Fig. 7). The number of first, second, third and forth order streams in the KRB are respectively, 354, 91, 26 and 7 (Table 2). Out of seven forth order streams, three contribute from the south of the KRB and four from the northern 


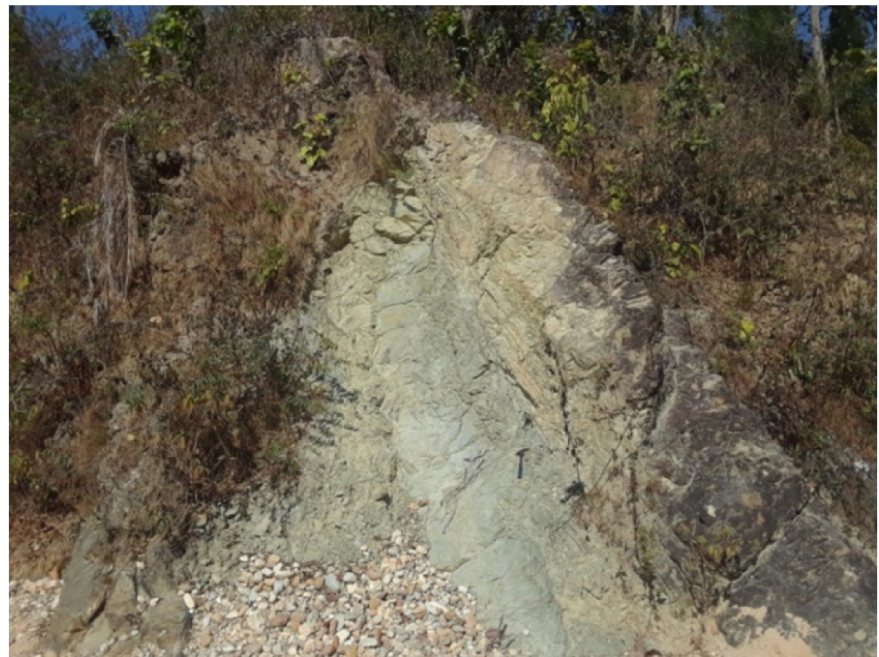

(a)

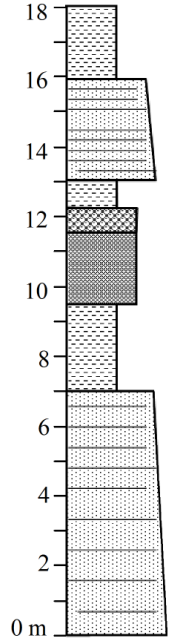

Green-grey mudstone

Thin bedded, medium- to finegrained grey sandstone

Green mudstone Reddish brown calcrete Green grey siltstone

Green mudstone

Thick bedded, fine-grained yellowish grey sandstone

Fig. 4: (a) Photograph showing Lower Siwalik observed near Ratomate (b) A graphic log of the part of the Lower Siwalik Subgroup, exposed east of Panesh near the MDT

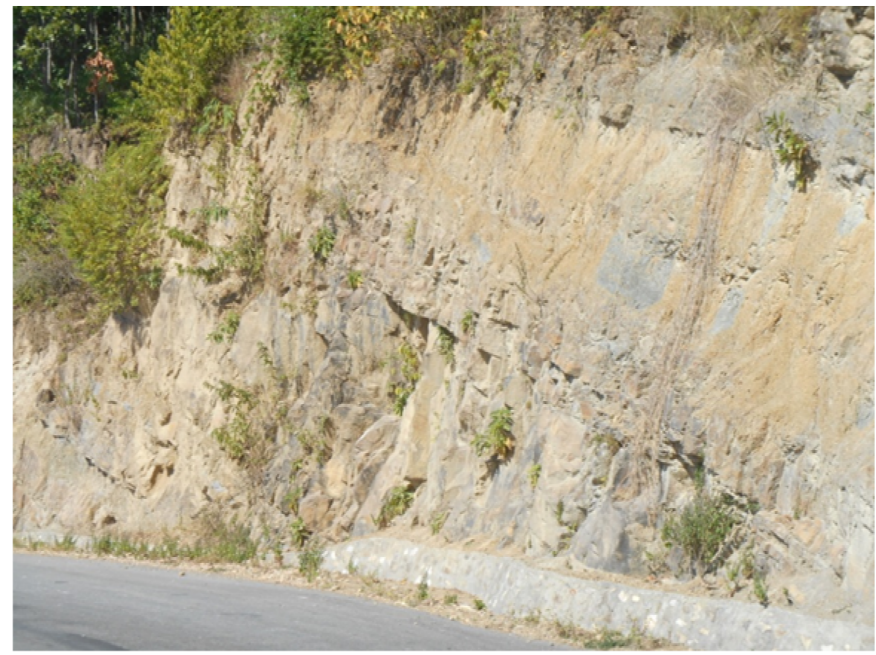

(a)

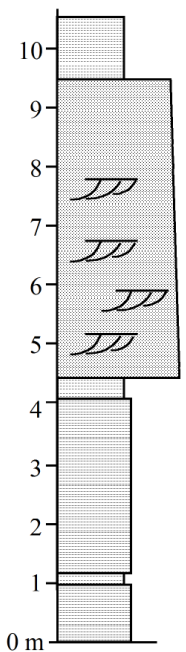

(b)
Brown mudstone

Thick cross-bedded, mediumgrained yellowish grey sandstone

Calcareous greenish grey mudstone

Spheroidally weathered greenish grey siltstone

Greenish grey mudstone Greenish grey siltstone

Fig. 5: The Middle Siwalik strata observed at the Sikharkateri village along the Kanti Rajpath; (a) Photograph facing the outcrop towards west on the uphill side, and (b) A grahic log from the same locality showing the lower part of the Middle Siwalik Subgroup

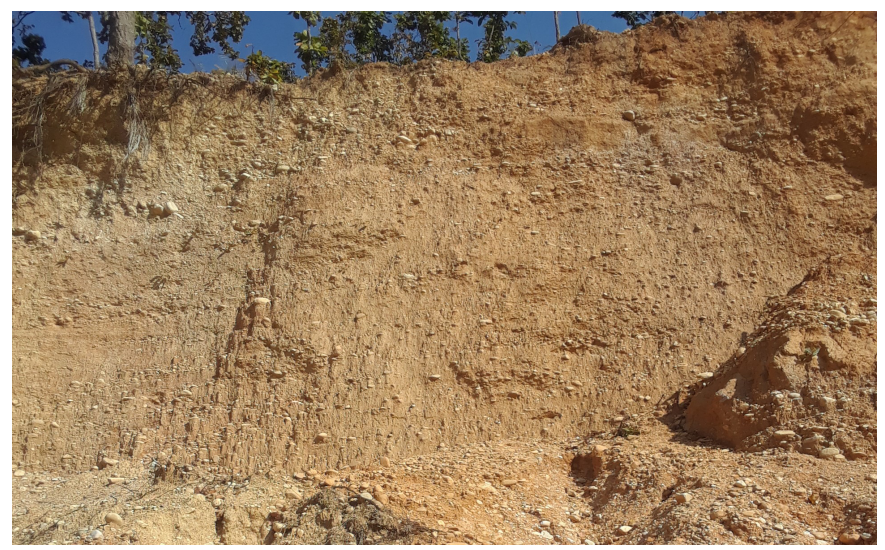

Fig. 6: Loosely consolidated, matrix-supported conglomerate of the Upper Siwalik Subgroup, exposed south of Bhorle 


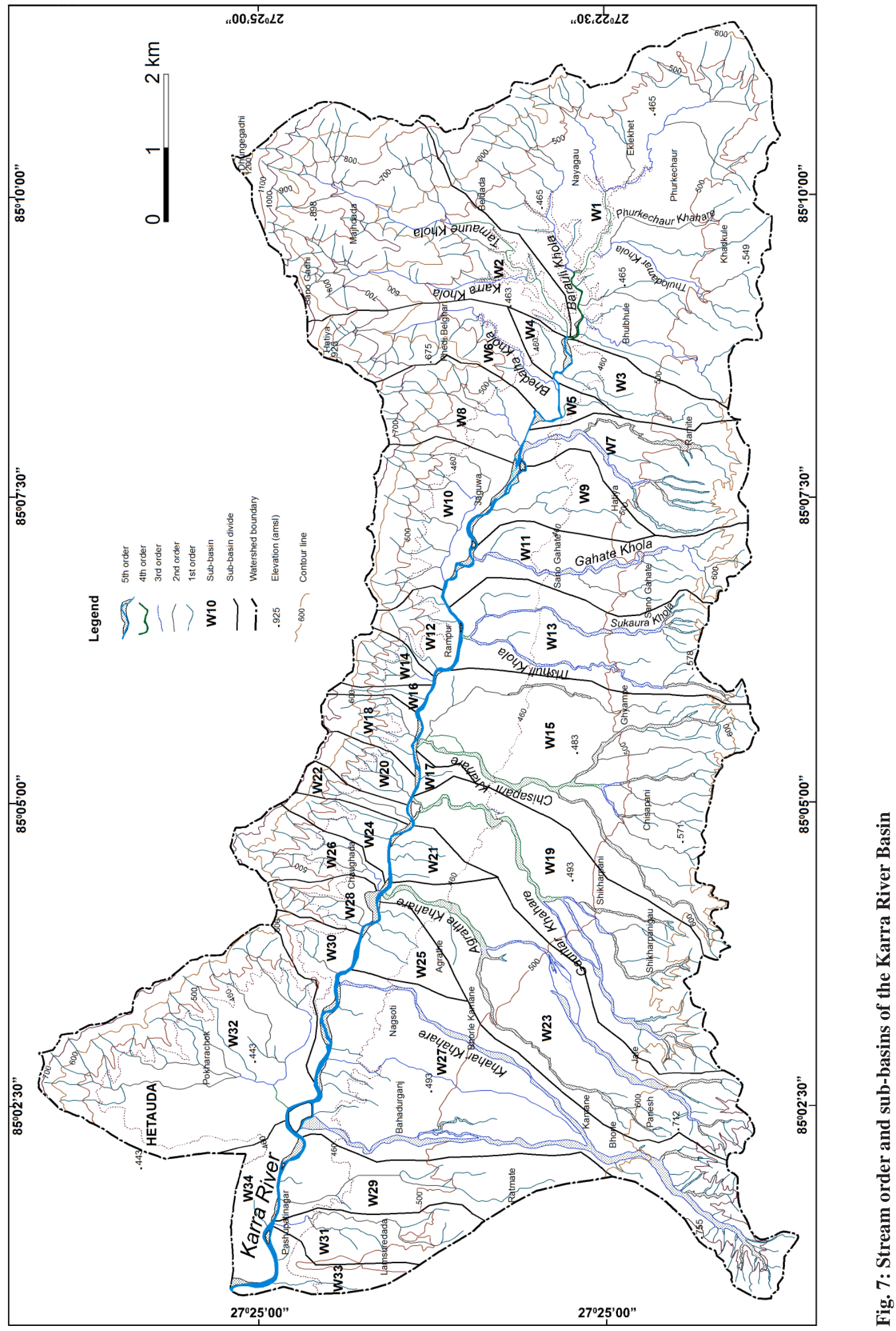


Table 2: Drainage network and basin geometrical properties of the Karra River Basin

\begin{tabular}{|c|c|c|c|c|c|c|c|c|c|c|c|c|c|c|}
\hline \multirow[t]{2}{*}{ Basin } & \multirow[t]{2}{*}{ Stream } & \multicolumn{5}{|c|}{$\begin{array}{c}\text { Stream number } \mathrm{Nu} \text { of } \\
\text { stream order }\end{array}$} & \multirow{2}{*}{$\begin{array}{c}\text { Total } \\
\mathrm{Nu}\end{array}$} & \multicolumn{5}{|c|}{ Bifurcation ratio, $\mathrm{Rb}$} & \multirow{2}{*}{$\begin{array}{c}\begin{array}{c}\text { Basin } \\
\text { perimeter, }\end{array} \\
\mathrm{P}(\mathrm{km})\end{array}$} & \multirow{2}{*}{$\begin{array}{l}\text { Basin } \\
\text { length } \\
\mathrm{Lb}(\mathrm{km})\end{array}$} \\
\hline & & $\mathrm{I}$ & II & III & IV & $\mathrm{V}$ & & $\mathrm{Rbl}$ & $\mathrm{Rb} 2$ & $\mathrm{Rb} 3$ & $\mathrm{Rb} 4$ & Mean & & \\
\hline W1 & IV & 47 & 14 & 5 & 1 & 0 & 67 & 3.36 & 2.8 & 5 & & 3.72 & 17.56 & 4.82 \\
\hline W2 & IV & 44 & 12 & 2 & 1 & & 59 & 3.67 & 6 & 2 & & 3.89 & 12.95 & 4.92 \\
\hline W3 & II & 2 & 1 & & & & 3 & 2.00 & & & & 2.00 & 5.97 & 2.33 \\
\hline W4 & I & 1 & & & & & 1 & & & & & & 2.75 & 1.12 \\
\hline W5 & I & 1 & & & & & 1 & & & & & & 3.37 & 0.58 \\
\hline W6 & III & 15 & 2 & 1 & & & 18 & 7.50 & 2 & & & 4.75 & 8.88 & 3.36 \\
\hline W7 & III & 10 & 3 & 1 & & & 14 & 3.33 & 3 & & & 3.17 & 8.58 & 3.02 \\
\hline W8 & III & 10 & 3 & 1 & & & 14 & 3.33 & 3 & & & 3.17 & 5.95 & 1.93 \\
\hline W9 & II & 2 & 1 & & & & 3 & 2.00 & & & & 2.00 & 6.34 & 2.20 \\
\hline W10 & III & 15 & 6 & 1 & & & 22 & 2.50 & 6 & & & 4.25 & 7.42 & 2.00 \\
\hline W11 & III & 11 & 4 & 1 & & & 16 & 2.75 & 4 & & & 3.38 & 10.32 & 3.75 \\
\hline W12 & I & 3 & & & & & 3 & & & & & & 3.77 & 1.21 \\
\hline W13 & IV & 15 & 5 & 2 & 1 & & 23 & 3.00 & 2.5 & 2 & & 2.50 & 11.24 & 3.94 \\
\hline W14 & III & 5 & 2 & 1 & & & 8 & 2.50 & 2 & & & 2.25 & 3.42 & 1.20 \\
\hline W15 & IV & 29 & 8 & 2 & 1 & & 40 & 3.63 & 4 & 2 & & 3.21 & 15.22 & 4.18 \\
\hline W16 & I & 1 & & & & & 1 & & & & & & 3.19 & 1.28 \\
\hline W17 & I & 1 & & & & & 1 & & & & & & 2.63 & 0.61 \\
\hline W18 & II & 5 & 1 & & & & 6 & 5.00 & & & & 5.00 & 4.12 & 1.33 \\
\hline W19 & IV & 23 & 6 & 2 & 1 & & 32 & 3.83 & 3 & 2 & & 2.94 & 13.16 & 5.48 \\
\hline W20 & II & 5 & 1 & & & & 6 & 5.00 & & & & 5.00 & 3.61 & 1.39 \\
\hline W21 & I & 3 & & & & & 3 & & & & & & 3.73 & 1.50 \\
\hline W22 & II & 2 & 1 & & & & 3 & 2.00 & & & & 2.00 & 3.79 & 1.59 \\
\hline W23 & IV & 18 & 5 & 2 & 1 & & 26 & 3.60 & 2.5 & 2 & & 2.70 & 14.13 & 5.93 \\
\hline W24 & I & 2 & & & & & 2 & & & & & & 4.66 & 1.48 \\
\hline W25 & I & 3 & & & & & 3 & & & & & & 4.63 & 1.63 \\
\hline W26 & III & 6 & 2 & 1 & & & 9 & 3.00 & 2 & & & 2.50 & 5.33 & 2.11 \\
\hline W27 & III & 33 & 4 & 1 & & & 38 & 8.25 & 4 & & & 6.13 & 18.60 & 7.11 \\
\hline W28 & II & 6 & 1 & & & & 7 & 6.00 & & & & 6.00 & 3.99 & 1.41 \\
\hline W29 & II & 5 & 1 & & & & 6 & 5.00 & & & & 5.00 & 10.42 & 4.49 \\
\hline W30 & II & 2 & 1 & & & & 3 & 2.00 & & & & 2.00 & 6.06 & 1.13 \\
\hline W31 & III & 5 & 2 & 1 & & & 8 & 2.50 & 2 & & & 2.25 & 6.31 & 2.68 \\
\hline W32 & IV & 21 & 5 & 2 & 1 & & 29 & 4.20 & 2.5 & 2 & & 2.90 & 11.38 & 3.41 \\
\hline W33 & I & 2 & & & & & 2 & & & & & & 6.22 & 1.88 \\
\hline W34 & I & 1 & & & & & 1 & & & & & & 6.07 & 0.95 \\
\hline Basin & V & 354 & 91 & 26 & 7 & 1 & 479 & 3.89 & 3.5 & 3.71 & 7 & 6.03 & 61.69 & 18.4104 \\
\hline
\end{tabular}

regions of the KRB. The basin comprises five first order, eight second order and nine third order sub-basins.

Bifurcation ratio $(\mathrm{Rb})$ : It is a ratio of the number of streams of a given order $(\mathrm{Nu})$ to the number of streams of the next higher order, i.e., $\mathrm{Nu}+1$ (Strahler, 1964). Bifurcation ratio is a dimensionless number that varies generally between 3 and 5 (Table 2). The higher values are attributed to watersheds suffering from high structural disturbances (Strahler, 1964). The mean bifurcation ratio varies from 2.0 to 6.13. Six subbasins (W6, W18, W20, W27, W28 and W29) show high (>4.75) $\mathrm{Rb}$ indicating high structural disturbances.
Perimeter $(\mathrm{P})$ : Perimeter $(\mathrm{P})$ of basin is the outer demarcation of the catchment measured along the divides between catchments. The KRB has perimeter of $61.69 \mathrm{~km}$ (Table 2). The sub-basins $\mathrm{W} 27$ and $\mathrm{W} 17$ have respectively, the highest $(18.6 \mathrm{~km})$ and the lowest $(2.63 \mathrm{~km})$ perimeters. Some of the sub-basins of larger perimeters are W1, W2, W15, W19, and W23.

Basin length ( $\mathrm{Lb}$ ): Basin length (Lb) is the longest dimension of the basin parallel to the principal drainage line (Schumm, 1956). Based on Schumm (1956)'s definition, the KRB has the basin length of $18.41 \mathrm{~km}$ (Table 2). Individual 
Table 3: Relief characteristics of the Karra River Basin

\begin{tabular}{|c|c|c|c|c|c|c|c|c|}
\hline \multirow[t]{2}{*}{ Basin } & \multirow[t]{2}{*}{ Stream } & \multicolumn{2}{|c|}{$\begin{array}{c}\text { Elevation in } \\
\text { basin }(\mathrm{m})\end{array}$} & \multirow{2}{*}{$\begin{array}{c}\begin{array}{c}\text { Basin } \\
\text { perimeter, }\end{array} \\
\mathrm{P}(\mathrm{m})\end{array}$} & \multirow{2}{*}{$\begin{array}{l}\text { Basin } \\
\text { length, } \\
\text { Lb } \\
(\mathrm{m})\end{array}$} & \multirow{2}{*}{$\begin{array}{c}\underset{\text { Basin }}{\text { relief (m) }} \\
\quad \text { H-h }\end{array}$} & \multirow{2}{*}{$\begin{array}{l}\text { Relative relief } \\
\operatorname{Rr}(\%)=(\mathrm{H}-\mathrm{h}) / \mathrm{P}\end{array}$} & \multirow{2}{*}{$\begin{array}{l}\text { Relief ratio } \\
\mathrm{Rh}=(\mathrm{H}-\mathrm{h}) / \mathrm{Lb}\end{array}$} \\
\hline & & $\begin{array}{c}\text { Max., } \\
\mathrm{H}\end{array}$ & $\begin{array}{c}\text { Min., } \\
\mathrm{h}\end{array}$ & & & & & \\
\hline W1 & IV & 838 & 458.0 & 17563 & 4824 & 380.0 & 2.2 & 0.08 \\
\hline W2 & IV & 1320 & 458.0 & 12949 & 4918 & 862.0 & 6.7 & 0.18 \\
\hline W3 & II & 641 & 454.0 & 5971 & 2332 & 187.0 & 3.1 & 0.08 \\
\hline W4 & I & 463 & 454.0 & 2750 & 1118 & 9.0 & 0.3 & 0.01 \\
\hline W5 & I & 475 & 453.0 & 3370 & 583 & 22.0 & 0.7 & 0.04 \\
\hline W6 & III & 1035 & 453.0 & 8880 & 3360 & 582.0 & 6.6 & 0.17 \\
\hline W7 & III & 644 & 451.5 & 8585 & 3016 & 192.5 & 2.2 & 0.06 \\
\hline W8 & III & 840 & 451.5 & 5951 & 1928 & 388.5 & 6.5 & 0.20 \\
\hline W9 & II & 530 & 450.5 & 6336 & 2196 & 79.5 & 1.3 & 0.04 \\
\hline W10 & III & 785 & 449.0 & 7424 & 2003 & 336.0 & 4.5 & 0.17 \\
\hline W11 & III & 637 & 449.7 & 10321 & 3751 & 187.3 & 1.8 & 0.05 \\
\hline W12 & I & 672 & 449.5 & 3765 & 1214 & 222.5 & 5.9 & 0.18 \\
\hline W13 & IV & 650 & 449.5 & 11241 & 3944 & 200.5 & 1.8 & 0.05 \\
\hline W14 & III & 690 & 449.0 & 3423 & 1198 & 241.0 & 7.0 & 0.20 \\
\hline W15 & IV & 640 & 447.8 & 15223 & 4177 & 192.2 & 1.3 & 0.05 \\
\hline W16 & I & 745 & 447.8 & 3190 & 1282 & 297.2 & 9.3 & 0.23 \\
\hline W17 & I & 455 & 447.6 & 2632 & 590 & 7.4 & 0.3 & 0.01 \\
\hline W18 & II & 745 & 447.7 & 4117 & 1333 & 297.3 & 7.2 & 0.22 \\
\hline W19 & IV & 695 & 447.5 & 13159 & 5479 & 247.5 & 1.9 & 0.05 \\
\hline W20 & II & 720 & 447.5 & 3612 & 1388 & 272.5 & 7.5 & 0.20 \\
\hline W21 & I & 472 & 447.0 & 3729 & 1504 & 25.0 & 0.7 & 0.02 \\
\hline W22 & II & 702 & 447.5 & 3788 & 1591 & 254.5 & 6.7 & 0.16 \\
\hline W23 & IV & 750 & 446.5 & 14132 & 5934 & 303.5 & 2.1 & 0.05 \\
\hline W24 & I & 702 & 447.0 & 4662 & 1480 & 255.0 & 5.5 & 0.17 \\
\hline W25 & I & 484 & 445.0 & 4632 & 1632 & 39.0 & 0.8 & 0.02 \\
\hline W26 & III & 754 & 446.5 & 5333 & 2113 & 307.5 & 5.8 & 0.15 \\
\hline W27 & III & 762 & 437.0 & 18603 & 7106 & 325.0 & 1.7 & 0.05 \\
\hline W28 & II & 640 & 446.0 & 3991 & 1409 & 194.0 & 4.9 & 0.14 \\
\hline W29 & II & 611 & 432.0 & 10418 & 4488 & 179.0 & 1.7 & 0.04 \\
\hline W30 & II & 640 & 438.0 & 6057 & 1133 & 202.0 & 3.3 & 0.18 \\
\hline W31 & III & 532 & 432.0 & 6312 & 2682 & 100.0 & 1.6 & 0.04 \\
\hline W32 & IV & 772 & 435.0 & 11383 & 3411 & 337.0 & 3.0 & 0.10 \\
\hline W33 & I & 522 & 430.0 & 6219 & 1881 & 92.0 & 1.5 & 0.05 \\
\hline W34 & I & 462 & 430.0 & 6071 & 953 & 32 & 0.5 & 0.03 \\
\hline Basin & V & 1320 & 430 & 61693 & 18410 & 890 & 1.4 & 0.05 \\
\hline
\end{tabular}

basin lengths of the thirty-four sub-basins vary from $0.6 \mathrm{~km}$ (W17) to $7.11 \mathrm{~km}$ (W27)

\section{Relief Aspects}

Basin relief (Bh): Basin relief (Bh) is the height difference between the mean elevation at outlet and the maximum elevation at catchment perimeter. The basin relief controls the amount of sediment that can be transported (Hadley and Schumm, 1961), and reflects understanding or erosional characteristics of the basin. The high basin relief is associated with high stream power and high rate of sediment transport. The northern sub-basins have generally higher relief (241-862 m) than the southern subbasins (100 to $380 \mathrm{~m}$; Table 3 ).
Relative relief (Rr): According to Melton (1957) relative relief $(\mathrm{Rr})$ is a ratio of basin relief to perimeter of the basin, and is expressed in percent. It is an actual relief compared to perimeter of the basin. It varies from 0.3 (W17, W4) to 9.3 (W16).

Relief ratio ( $\mathrm{Rh}$ ): Ratio of maximum relief to the basin length is known as relief ratio (Schumm, 1956) or as relieflength ratio. Relief ratio ( $\mathrm{Rh})$ is regarded as an important parameter because it is well correlated with hydrological characteristics and drainage area and is a good predictor of sediment yield in the basin, as the higher the Rh the greater the stream power and sediment transport capacity. Relief ratio of the KRB ranges from 0.008 to 0.232 (Table 3). Considering upto the third order streams, Rh ranges from 0.037 to 0.079 for 
Table 4: Areal aspect of the Karra River Basin

\begin{tabular}{|c|c|c|c|c|c|}
\hline Basin & Stream & $\begin{array}{l}\begin{array}{c}\text { Basin } \\
\text { area, }\end{array} \\
\mathrm{A}\left(\mathrm{km}^{2}\right)\end{array}$ & $\begin{array}{c}\text { Circular } \\
\text { Basin area, } \\
\text { Ac } \\
\left(\mathrm{P}^{2} / 4 \pi\right)\left(\mathrm{km}^{2}\right)\end{array}$ & 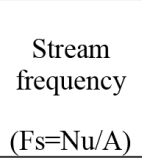 & $\begin{array}{c}\text { Circularity } \\
\text { ratio, Rc } \\
(4 \pi \mathrm{A}) / \mathrm{P}^{2}\end{array}$ \\
\hline W1 & IV & 14.49 & 24.55 & 4.62 & 0.59 \\
\hline W2 & IV & 7.98 & 13.34 & 7.39 & 0.60 \\
\hline W3 & II & 1.30 & 2.84 & 2.31 & 0.46 \\
\hline W4 & I & 0.37 & 0.60 & 2.67 & 0.62 \\
\hline W5 & I & 0.24 & 0.90 & 4.12 & 0.27 \\
\hline W6 & III & 2.66 & 6.28 & 6.77 & 0.42 \\
\hline W7 & III & 3.13 & 5.86 & 4.48 & 0.53 \\
\hline W8 & III & 2.02 & 2.82 & 6.93 & 0.72 \\
\hline W9 & II & 1.57 & 3.19 & 1.91 & 0.49 \\
\hline W10 & III & 2.90 & 4.39 & 7.58 & 0.66 \\
\hline W11 & III & 3.23 & 8.48 & 4.95 & 0.38 \\
\hline W12 & I & 0.80 & 1.13 & 3.75 & 0.71 \\
\hline W13 & IV & 3.99 & 10.06 & 5.77 & 0.40 \\
\hline W14 & III & 0.62 & 0.93 & 12.84 & 0.67 \\
\hline W15 & IV & 8.87 & 18.44 & 4.51 & 0.48 \\
\hline W16 & I & 0.22 & 0.81 & 4.51 & 0.27 \\
\hline W17 & I & 0.19 & 0.55 & 5.23 & 0.35 \\
\hline W18 & II & 0.81 & 1.35 & 7.36 & 0.60 \\
\hline W19 & IV & 6.04 & 13.78 & 5.30 & 0.44 \\
\hline W20 & II & 0.73 & 1.04 & 8.23 & 0.70 \\
\hline W21 & I & 0.67 & 1.11 & 4.50 & 0.60 \\
\hline W22 & II & 0.43 & 1.14 & 7.03 & 0.37 \\
\hline W23 & IV & 6.11 & 15.89 & 4.26 & 0.38 \\
\hline W24 & I & 0.73 & 1.73 & 2.75 & 0.42 \\
\hline W25 & I & 1.02 & 1.71 & 2.95 & 0.60 \\
\hline W26 & III & 1.29 & 2.26 & 6.96 & 0.57 \\
\hline W27 & III & 8.88 & 27.54 & 4.28 & 0.32 \\
\hline W28 & II & 0.75 & 1.27 & 9.34 & 0.59 \\
\hline W29 & II & 2.87 & 8.64 & 2.09 & 0.33 \\
\hline W30 & II & 0.94 & 2.92 & 3.21 & 0.32 \\
\hline W31 & III & 1.56 & 3.17 & 5.13 & 0.49 \\
\hline W32 & IV & 7.37 & 10.31 & 3.94 & 0.71 \\
\hline W33 & I & 0.82 & 3.08 & 2.43 & 0.27 \\
\hline W34 & I & 1.16 & 2.93 & 0.87 & 0.39 \\
\hline Basin & V & 98.79 & 302.9 & 4.85 & 0.33 \\
\hline
\end{tabular}

southern basins, and 0.099 to 0.201 for northern basins. It means that the larger northern sub-basins have distinctly higher range of $\mathrm{Rh}$ compared to $\mathrm{Rh}$ of the southern sub-basin.

\section{Areal Aspects}

Basin area (A): It is an area enclosed by the perimeter length of the catchment divide. Basin area is an important parameter because sediment transport is well related to the basin area. The KRB as a whole has an area of 98.79 sq. km (Table 4). Basin area as a whole ranges from 0.22 (W16) to 14.49 (W1). The third order southern sub-basins have basin areas in the range of 3.13-14.49 sq. km, while the third order northern sub-basins have range of $0.62-7.98 \mathrm{sq}$. $\mathrm{km}$. This means that the sub-basins in the southern region are somewhat larger than the sub-basin of the northern region.

Stream frequency (Fs): The stream frequency is a number of streams per unit area of the drainage sub-basins. It is an indicator of landscape evolution, and for the KRB, it ranges from 0.87 to 12.84 (Table 4 ). The high stream frequency is obtained for higher than third order sub-basins of the northern region (W2, W6, W8, W10, W14, W26 and W32) and southern region (W1, W7, W13, W19, W23, W27 and W31).

Circularity ratio $(\mathrm{Rc})$ : This morphometric property is a ratio of area of the basin to the area of a circle having the same perimeter as the basin according to Miller (1953). Circularity ratio near 1.0 indicates near circularity and old stage of stream development. Rc of the sub-basins of the southern region ranges between 0.32 and 0.59 indicating their elongate nature, whereas those of the northern sub-basins show 0.42-0.71 (Table 4), most often circular sub-basins. Low circularity ratio is associated with elongate basins of homogeneous ground and similar high permeability.

\section{Hypsometric Analysis}

Hypsometric curve: Hypsometric analysis, i.e., the relation of horizontal cross-sectional drainage basin area to elevation was developed by Longbein and others (1947). Method of hypsometric analysis based on Strahler (1952) was followed to establish hypsometric curves for each of the thirty-four subbasins. The relative height, i.e., the ratio of height of the contour from the base of the sub-basins to the maximum basin elevation upto a remote point on catchment divide of the sub-basin, was obtained. The relative area was obtained from the ratio of area above a particular contour to the total basin area. The relative heights versus relative areas from the higher elevation contours to the outlet of the sub-basins were plotted to obtain a hypsometric curve (Fig. 8). The shape of hypsometric curves shows that curves can be distinguished into the following types: (a) nonequilibrium convex down or straight curves (W4, W17, W25, W31 and W34), (b) concave curve close to equilibrium (W5, W7, W11, W15, W19, W27, W29, W33) and (c) extremely concave up curves with low hypsometric integral values (0.14-0.33), for example W1, W2, W3, W6, W8, W9, W10, W12, W13, W14, W16, W18, W20, W21, W22, W23, W24, W26, W28, W30 and W32 showing stable or Monadnock phase. Sub-basins in non-equilibrium are all of first order sub-basins except W31, which is the third order sub-basin.

Hypsometric integral: HI of the southern sub-basins varies from 0.15 to 0.59 whereas $\mathrm{HI}$ of the northern sub-basins from 0.17 to 0.30 (Table 5). The northern sub-basins show greater removal of landscapes volume from the sub-basin compared to the southern sub-basins, and are varying between Monadnock phase to mature stage. As the HI of the southern sub-basin mostly vary from 0.3 to 0.5 , the basin development stage is nearly in mature stage and the sub-basins are therefore in near equilibrium stage. 

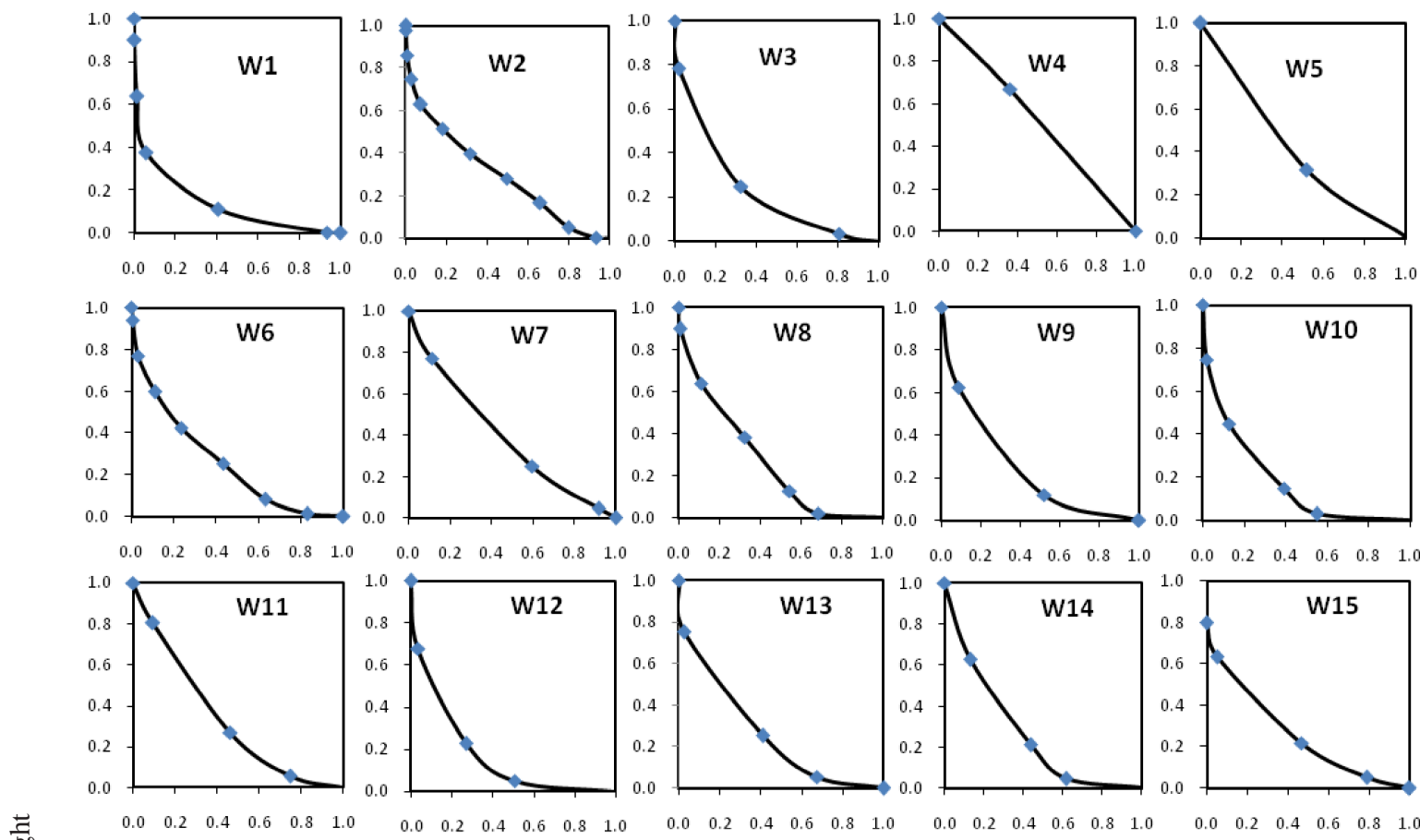

$\begin{array}{llllll}0.0 & 0.2 & 0.4 & 0.6 & 0.8 & 1.0\end{array}$

$\begin{array}{llllll}0.0 & 0.2 & 0.4 & 0.6 & 0.8 & 1.0\end{array}$

$\begin{array}{llllll}0.0 & 0.2 & 0.4 & 0.6 & 0.8 & 1.0\end{array}$
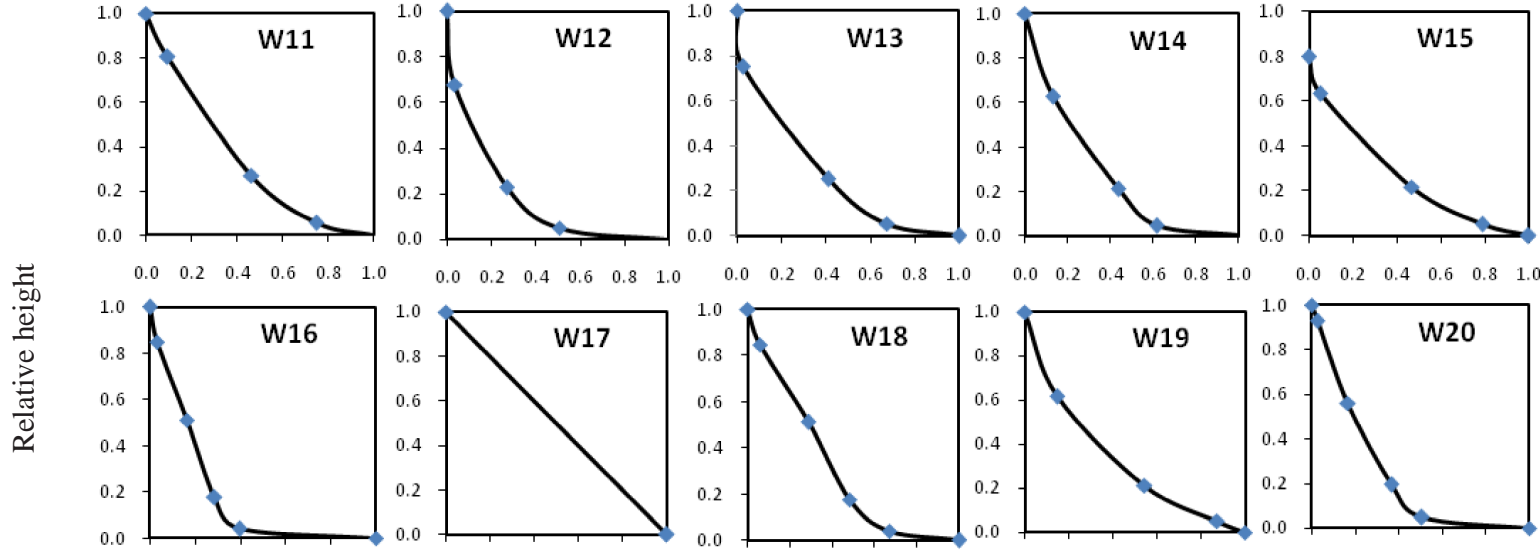

$\begin{array}{llllll}0.0 & 0.2 & 0.4 & 0.6 & 0.8 & 1.0\end{array}$
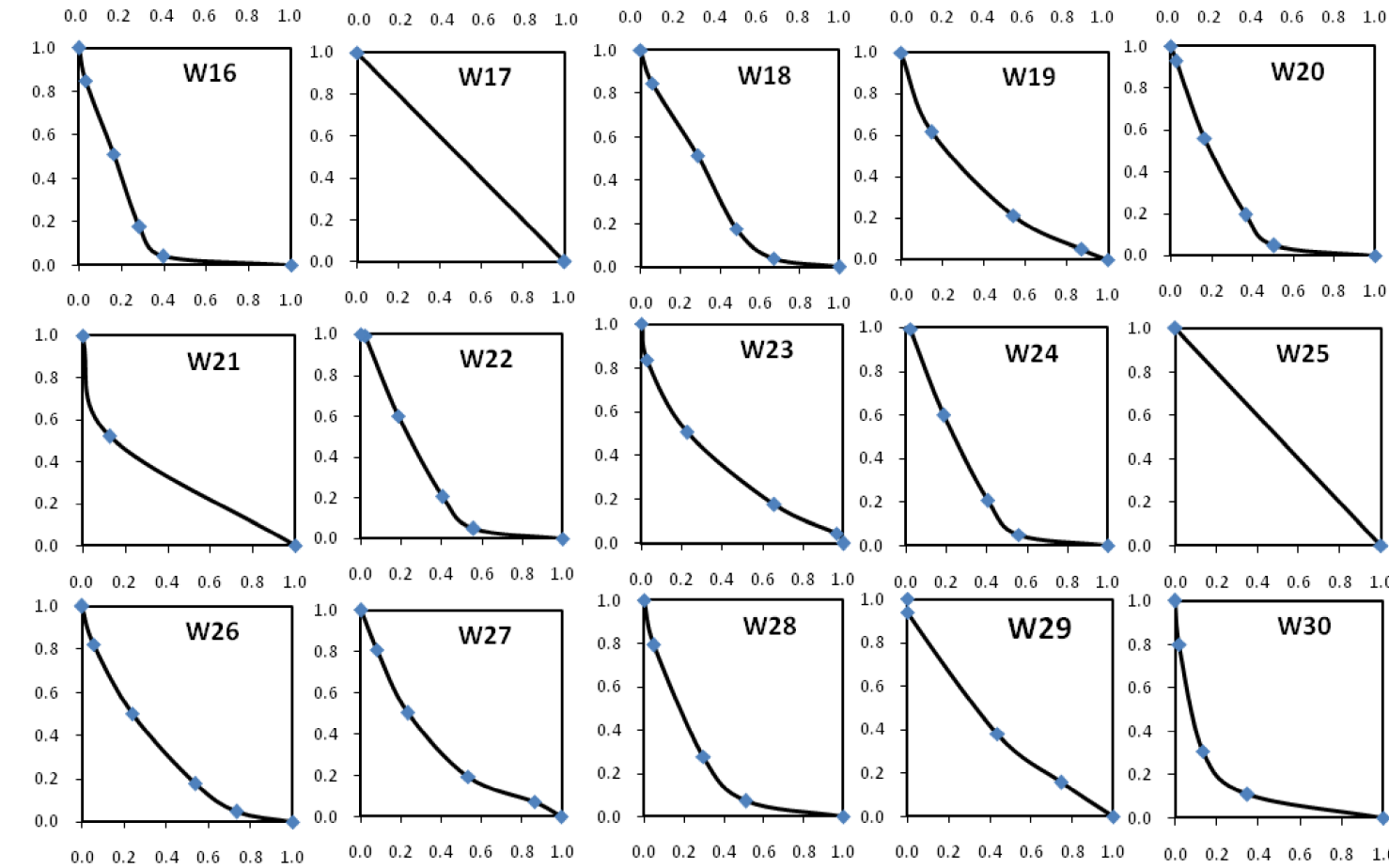

$\begin{array}{llllll}0.0 & 0.2 & 0.4 & 0.6 & 0.8 & 1.0\end{array}$
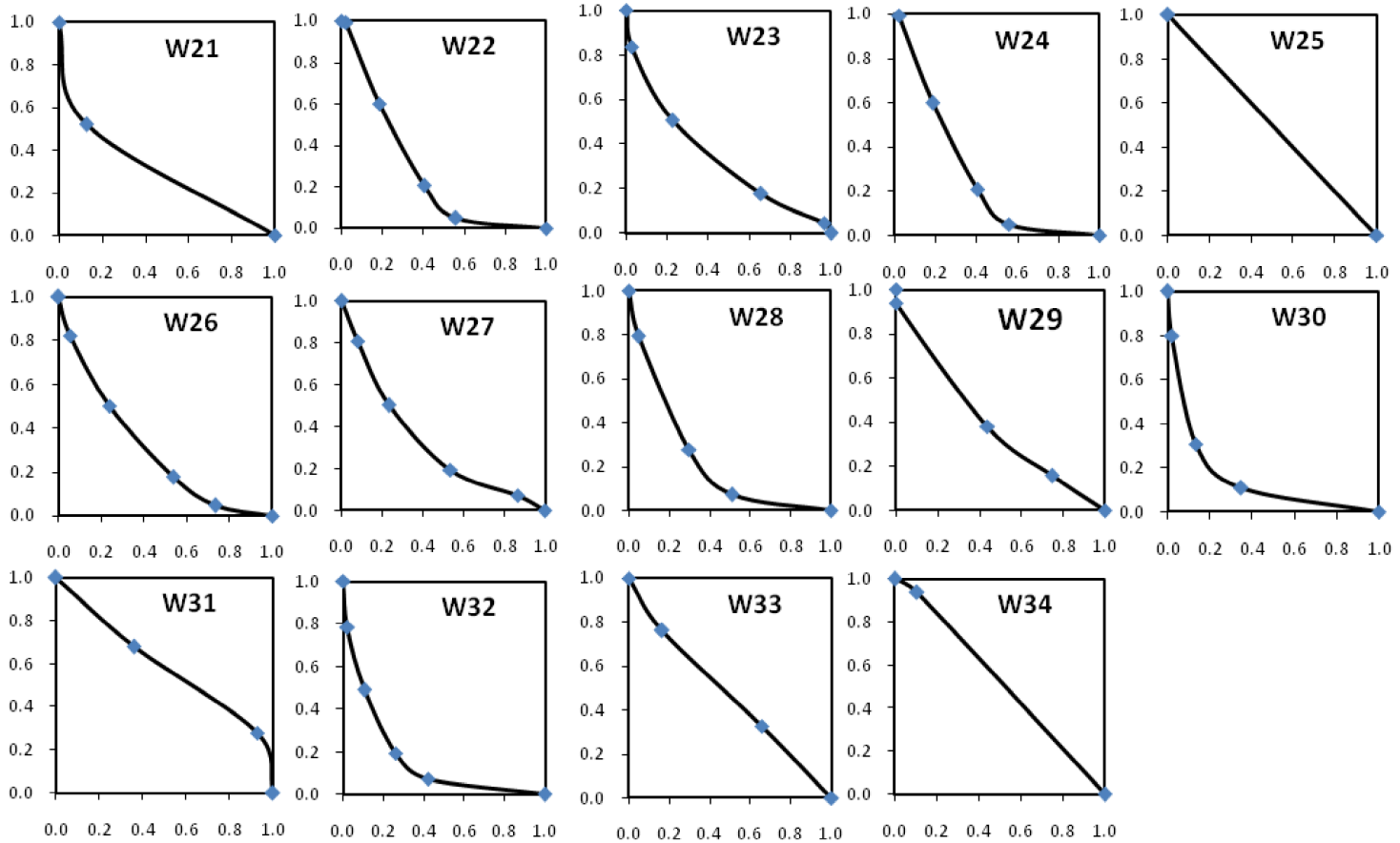

$\begin{array}{lllllll}0.0 & 0.2 & 0.4 & 0.6 & 0.8 & 1.0\end{array}$

$\begin{array}{llllll}0.0 & 0.2 & 0.4 & 0.6 & 0.8 & 1.0\end{array}$

Relative area

Fig. 8: Hypsometric curves of thirty-four sub-basins of the Karra River Basin. The $x$-axis represents relative area and the $y$-axis represents relative height. 
Table 5: Hypsometric integral and empirically estimated specific sediment yield and sediment delivery ratio of the Karra River Basin

\begin{tabular}{|c|c|c|c|c|c|c|c|c|c|c|c|}
\hline Basin & Stream & $\begin{array}{c}\text { Basin } \\
\text { relief, } \\
\text { H-h, } \\
\text { (m) }\end{array}$ & $\begin{array}{l}\text { Elv. } \\
\text { mean } \\
(\mathrm{m})\end{array}$ & $\begin{array}{c}\text { Basin } \\
\text { length, } \\
\text { Lb } \\
(\mathrm{m})\end{array}$ & $\begin{array}{c}\text { Drainage } \\
\text { lengh, } \\
\text { Ld (m) }\end{array}$ & $\begin{array}{c}\text { Relief } \\
\text { ratio, } \\
\text { Rh }\end{array}$ & $\begin{array}{c}\text { Basin } \\
\text { area, } \\
\text { A } \\
\left(\mathrm{km}^{2}\right)\end{array}$ & $\mathrm{HI}$ & SDR & $\begin{array}{c}\ln (\mathrm{SSY}) \\
\left(\begin{array}{c}\mathrm{t} \mathrm{ha}^{-1} \mathrm{yr}^{-} \\
\mathrm{l}\end{array}\right)\end{array}$ & $\begin{array}{l}\text { (SSY) } \\
(\mathrm{t} \mathrm{ha-} \\
\left.{ }^{\mathrm{l}} \mathrm{yr}^{-1}\right)\end{array}$ \\
\hline W1 & IV & 380.0 & 514.5 & 4824 & 5901 & 0.08 & 14.49 & 0.15 & 0.20 & 1.0 & 2.8 \\
\hline W2 & IV & 862.0 & 710.3 & 4918 & 6022 & 0.18 & 7.98 & 0.29 & 0.23 & 0.9 & 2.5 \\
\hline W3 & II & 187.0 & 499.4 & 2332 & 2846 & 0.08 & 1.30 & 0.24 & 0.33 & 2.3 & 9.8 \\
\hline W4 & I & 9.0 & 458.6 & 1085 & 864 & 0.01 & 0.38 & 0.51 & 0.42 & 2.4 & 11.1 \\
\hline W5 & I & 22.0 & 462.1 & 583 & 774 & 0.04 & 0.24 & 0.42 & 0.45 & 2.9 & 18.0 \\
\hline W6 & III & 582.0 & 600.8 & 3360 & 4140 & 0.17 & 2.66 & 0.25 & 0.29 & 1.8 & 5.9 \\
\hline W7 & III & 192.5 & 527.7 & 3016 & 3629 & 0.06 & 3.13 & 0.40 & 0.28 & 1.3 & 3.5 \\
\hline W8 & III & 388.5 & 554.0 & 1928 & 2339 & 0.20 & 2.02 & 0.26 & 0.31 & 1.9 & 6.5 \\
\hline W9 & II & 79.5 & 471.3 & 2196 & 2248 & 0.04 & 1.57 & 0.26 & 0.32 & 2.1 & 7.8 \\
\hline W10 & III & 336.0 & 510.6 & 2003 & 3174 & 0.17 & 2.90 & 0.18 & 0.28 & 1.9 & 7.0 \\
\hline W11 & III & 187.3 & 512.3 & 3751 & 4494 & 0.05 & 3.23 & 0.33 & 0.28 & 1.4 & 4.1 \\
\hline W12 & I & 222.5 & 489.2 & 1214 & 1137 & 0.18 & 0.80 & 0.18 & 0.36 & 2.8 & 16.2 \\
\hline W13 & IV & 200.5 & 502.3 & 3944 & 4643 & 0.05 & 3.99 & 0.26 & 0.27 & 1.5 & 4.3 \\
\hline W14 & III & 241.0 & 513.0 & 1198 & 1344 & 0.20 & 0.62 & 0.27 & 0.38 & 2.7 & 14.2 \\
\hline W15 & IV & 192.2 & 510.7 & 4177 & 6074 & 0.05 & 8.87 & 0.33 & 0.23 & 0.7 & 2.1 \\
\hline W16 & I & 297.2 & 502.7 & 1282 & 1030 & 0.23 & 0.22 & 0.18 & 0.46 & 3.7 & 39.3 \\
\hline W17 & I & 7.4 & 451.3 & 590 & 530 & 0.01 & 0.17 & 0.50 & 0.47 & 2.9 & 18.8 \\
\hline W18 & II & 297.3 & 537.5 & 1333 & 1350 & 0.22 & 0.81 & 0.30 & 0.36 & 2.4 & 10.5 \\
\hline W19 & IV & 247.5 & 528.8 & 5479 & 6740 & 0.05 & 6.04 & 0.33 & 0.25 & 1.0 & 2.8 \\
\hline W20 & II & 272.5 & 511.2 & 1388 & 1241 & 0.20 & 0.73 & 0.23 & 0.37 & 2.6 & 14.0 \\
\hline W21 & I & 25.0 & 455.1 & 1504 & 983 & 0.02 & 0.67 & 0.32 & 0.38 & 2.4 & 11.0 \\
\hline W22 & II & 254.5 & 516.7 & 1591 & 1554 & 0.16 & 0.43 & 0.27 & 0.41 & 2.9 & 18.5 \\
\hline W23 & IV & 303.5 & 530.9 & 5934 & 6947 & 0.05 & 6.11 & 0.28 & 0.25 & 1.1 & 3.2 \\
\hline W24 & I & 255.0 & 482.1 & 1480 & 1451 & 0.17 & 0.73 & 0.14 & 0.37 & 3.1 & 22.2 \\
\hline W25 & I & 39.0 & 464.5 & 1632 & 727 & 0.02 & 1.02 & 0.50 & 0.35 & 1.7 & 5.5 \\
\hline W26 & III & 307.5 & 538.5 & 2113 & 2560 & 0.15 & 1.29 & 0.30 & 0.33 & 2.1 & 8.1 \\
\hline W27 & III & 325.0 & 543.1 & 7106 & 7895 & 0.05 & 8.88 & 0.33 & 0.23 & 0.8 & 2.1 \\
\hline W28 & II & 194.0 & 491.0 & 1409 & 1633 & 0.14 & 0.75 & 0.23 & 0.37 & 2.7 & 14.2 \\
\hline W29 & II & 179.0 & 502.3 & 4488 & 4124 & 0.04 & 2.87 & 0.39 & 0.29 & 1.3 & 3.8 \\
\hline W30 & II & 202.0 & 470.7 & 1133 & 1254 & 0.18 & 0.94 & 0.16 & 0.35 & 2.8 & 15.9 \\
\hline W31 & III & 100.0 & 490.6 & 2682 & 3153 & 0.04 & 1.56 & 0.59 & 0.32 & 1.4 & 4.1 \\
\hline W32 & IV & 337.0 & 491.7 & 3411 & 3842 & 0.10 & 7.37 & 0.17 & 0.24 & 1.4 & 3.9 \\
\hline W33 & I & 92.0 & 473.0 & 1881 & 1214 & 0.05 & 0.82 & 0.47 & 0.36 & 2.0 & 7.1 \\
\hline W34 & I & 32.0 & 446.7 & 953 & 494 & 0.03 & 1.16 & 0.52 & 0.34 & 1.5 & 4.6 \\
\hline
\end{tabular}

\section{SEDIMENT DELIVERY RATIO AND SEDIMENT YIELD PREDICTED}

Morphometric properties have been used as input of explanatory variables to explain SDR and specific sediment yield (SSY) of the KRB to figure out variation of SDR and SSY among the sub-basins. Sediment delivery ratio (SDR) is expressed as ratio of sediment yield of a drainage basin to a gross erosion (Roehl, 1962; Walling, 1983). SDR is related with physiography of the drainage basin; basin length and drainage length (Fig. 9). Both relationships show good inverse correlation of SDR with basin length and drainage length. Short drainage basins with steep slope deliver more sediment compared to long and flat drainage basins. The SDR estimated for the southern sub-basins ranges from 0.20 (W1) to 0.45 (W5), whereas it ranges from 0.23 (W2) to 0.46 (W16) for the northern basins (Table 5). Because SDR is inversely proportional to the basin area, higher SDR can be expected compared to the estimated SDR for the upstream segments of the drainage basins.

Considering SDR of sub-basins, the third order and forth order sub-basins have lower SDR, compared to the first and second order sub-basins have (Table 6 and Fig. 10). Since the southern sub-basins are larger compared to the northern subbasins, their SDR is lower $(<0.3)$ compared to the norther subbasins. In the northern sub-basins, which are mostly of I and 


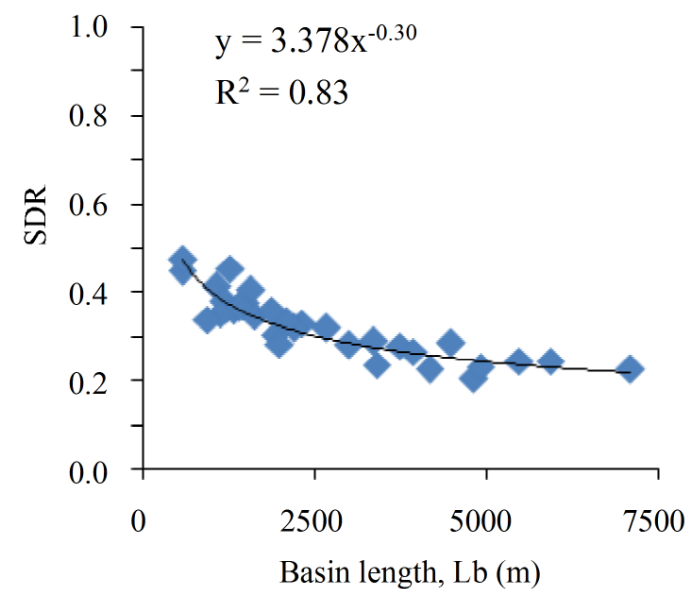

(a)

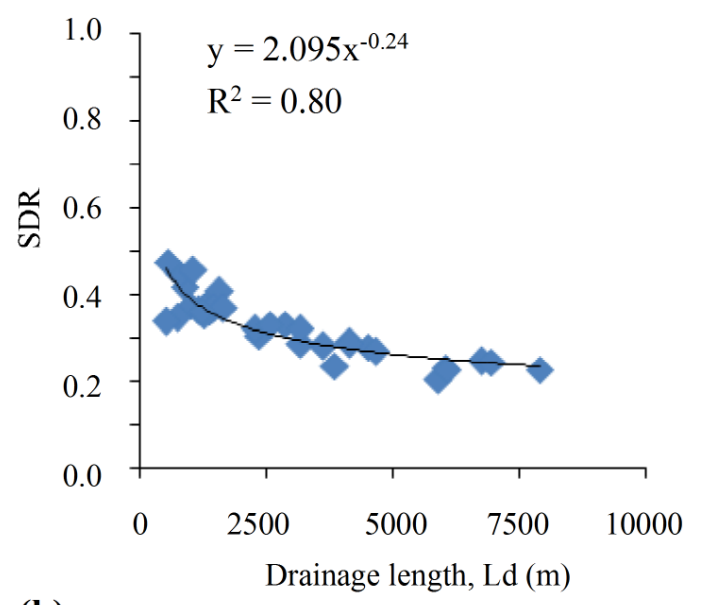

(b)

Fig. 9: Relationships between SDR and (a) basin length and (b) drainage length

II order sub-basins, SDR exceeds 0.3 (Table 6).

The southern sub-basins possess SSY varying from 2.1 to 18.8 tons ha $^{-1} \mathrm{yr}^{-1}$ and the northern sub-basins possess SSY ranging from 2.5 to 39.3 tons tons $\mathrm{ha}^{-1} \mathrm{yr}^{-1}$. Generally, I to II order sub-basins of the northern region have SSY more than 10 tons per hectare per year (Table 5; Fig. 11). The northern subbasins have higher potential of specific sediment yield considering the morphometric properties. It is obvious from the estimated figures of sediment delivery ratio and specific sediment

Table 6: Ranges of SDR of the northern and southern subbasins of the Karra River Basin

\begin{tabular}{l|l|l|l|l}
\hline SDR & $\begin{array}{l}\text { Northern } \\
\text { sub-basins }\end{array}$ & $\begin{array}{l}\text { Stream } \\
\text { order }\end{array}$ & $\begin{array}{l}\text { Southern } \\
\text { sub- } \\
\text { basins }\end{array}$ & $\begin{array}{l}\text { Stream } \\
\text { order }\end{array}$ \\
\hline $0.2-0.3$ & W2 & IV & W1 & IV \\
& W6 & III & W7 & III \\
& W10 & III & W11 & III \\
& W32 & IV & W13 & IV \\
& & & W15 & IV \\
& & & W23 & IV \\
& & & W27 & III \\
& & & W29 & II \\
$0.3-0.4$ & W8 & III & W3 & II \\
& W12 & I & W9 & II \\
& W14 & III & W21 & I \\
& W18 & II & W25 & I \\
& W20 & II & W31 & III \\
& W24 & I & W33 & I \\
& W26 & III & & \\
& W28 & II & & \\
& W30 & II & & \\
& W34 & I & & \\
& W4 & I & W17 & I \\
$0.4-0.5$ & W16 & I & W5 & I \\
& W22 & II & & \\
\hline
\end{tabular}

yield that the central northern sub-basins have not only higher SDR but also have higher SSY compared to the southern subbasins (Figs. 10 and11).

\section{CONCLUSIONS}

The Karra River is the fifth order axial drainage system, developed subparallel to the hinge of the anticline, and contributed by tributaries in trellis pattern. Altogether thirty-four sub-basins make up the Karra River Basin that has length of $18.41 \mathrm{~km}$, area of $98.79 \mathrm{sq}$. km, and relief ratio of $0.008-0.232$. The southern drainage sub-basins are more elongate compared to the northern sub-basins. The northern sub-basins have higher relief and smaller basin area and lengths compared to the southern sub-basins.

Based on hypsometric analysis, the southern sub-basins are mostly of mature to unstable phase, whereas the northern sub-basins are of Monadnock phase to mature stage of basin development. HI of the southern sub-basins varies from 0.15 to 0.59 and northern sub-basin from 0.17 to 0.30 , suggesting greater removal of landscape from the northern sub-basins compared to the southern ones. Sediment delivery ratio (SDR) and specific sediment yield (SSY) estimated for the southern sub-basins of the KRB are lower compared to those estimated for the northern sub-basins. Considering the geology of the KRB and hypsometric integral, the southern sub-basins are vulnerable to erosion because of two reasons: firstly, they are geomorphologically mature to unstable in stage of development, and secondly, unconsolidated sediments are dominantly distributed in this region and are more erodible compared to bedrocks of the northern sub-basins. Relatively permeable unconsolidated sand and gravel terrain compared to the northern sub-basins with mostly of less permeable bedrocks of sandstone and mudstone perhaps yields low figure of specific sediment yield and SDR because the southern sub-basins are elongate and therefore, eroded sediments can be admitted and captured in the downstream stretch of the sub-basins as fans. Large 


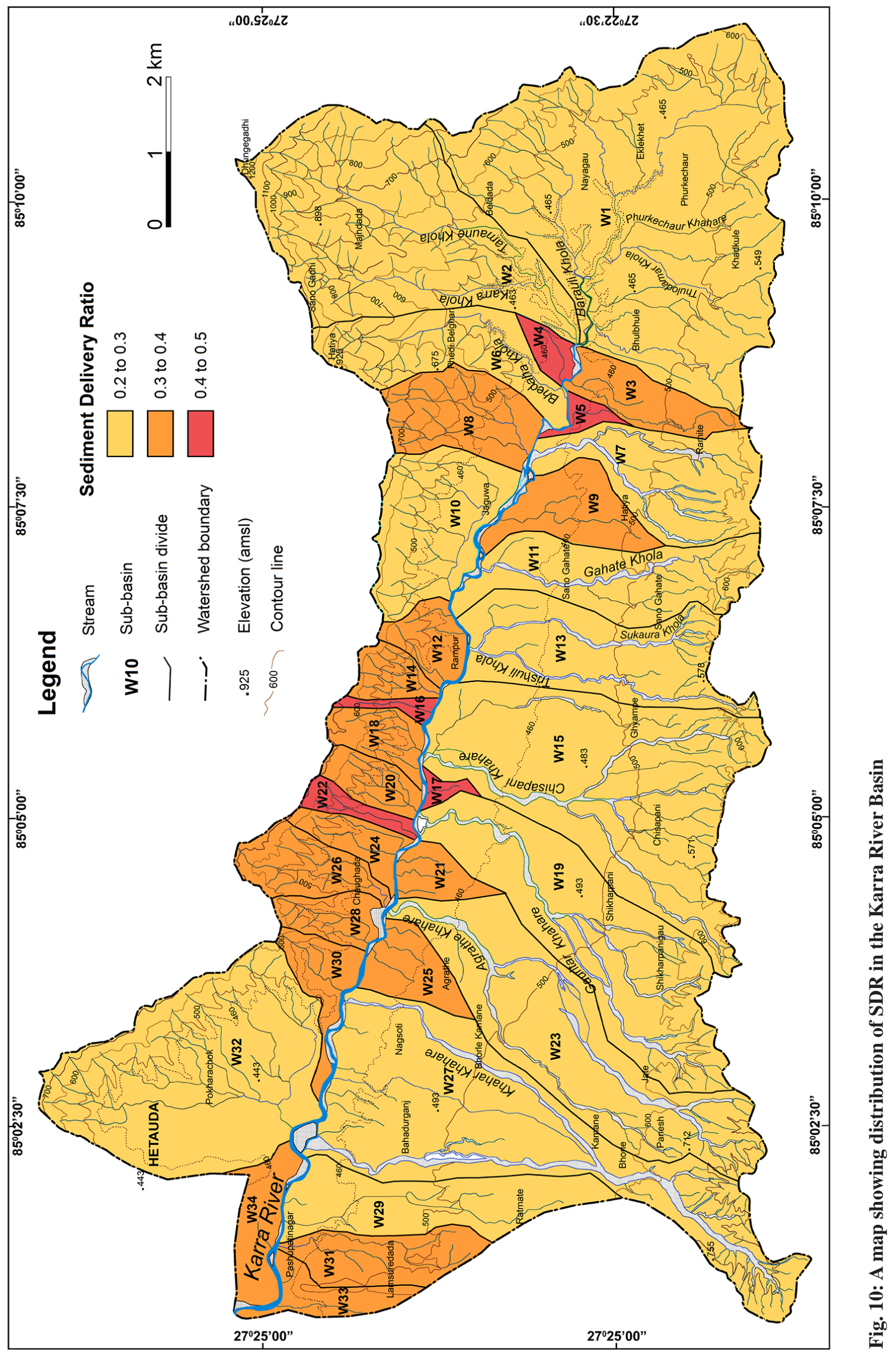




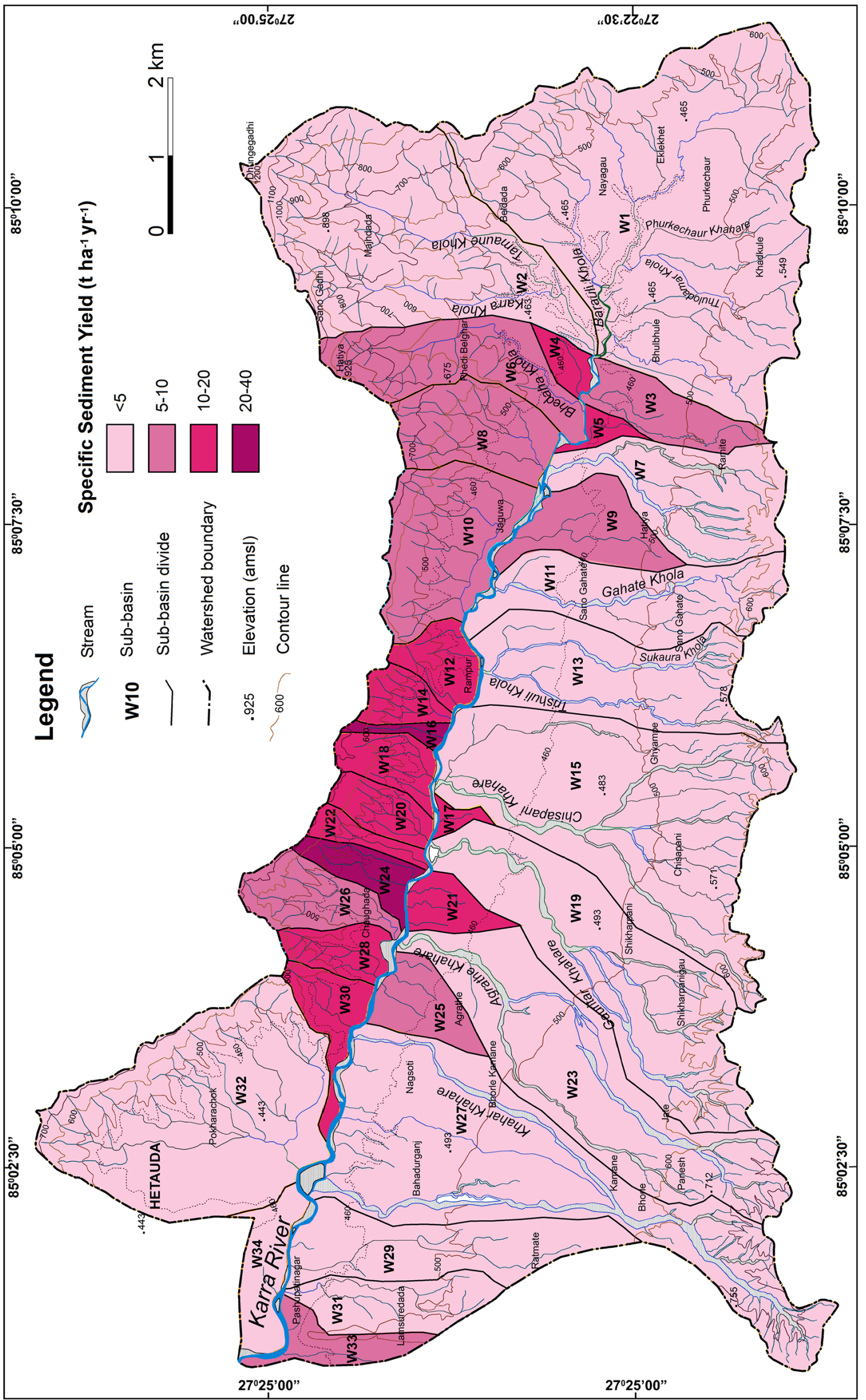

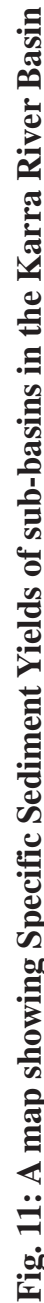


drainage basins with gentle slopes perhaps deliver low sediment compared to short and steep drainage basins, as evidenced from the relationships between SDR and basin length and drainage length. However, hydrology and sediment transport mechanism perhaps influence the specific sediment yield of the basin. The morphometric derived estimated SSY may differ significantly with measured SSY as factors other than morphometry of the drainage basins may contribute in variation of specific sediment yield.

\section{ACKNOWLEDGEMENTS}

Authors are thankful to Central Department of Geology for providing necessary facilities to conduct fieldworks. Authors would like to thank Dinesh Sharma, Raj Kumar Ghising Lama and Om Khadka for providing finanacial support. Authors thank Suman Roka, Ananta Joshi, Manju Subedi, Suman Shrestha, and Rhuthum Rai for their cooperation during field survey.

\section{REFERENCES}

Dedkov, A.P., 2004, The relationship between sediment yield and drainage basin area. In: Sediment Transfer through the Fluvial System. Publication 288, International Association of Hydrological Sciences, Wallingford, pp. 197-204.

de Boer, D.H. and Crosby, G., 1996, Specific sediment yield and drainage basin scale. Erosion and sediment yield: Global and regional perspectives (Proceedings of the Exeter Symposium, July 1996). IAHS Publication no. 236, pp. 333-338.

de Vente, J., Verduyn, R., Verstraeten, G., Vanmaercke, M., and Poesen, J., 2011, Factors controlling sediment yield at the catchment scale in NW Mediterranean geoecosystems. J. Soils Sediments, v. 11, pp. 690-707. DOI 10.1007/s11368011-0346-3

Didone, E.J., Minella, J.P.G., and Merten, G.H., 2015, Quatifying soil erosion and sediment yield in a catchment in southern Barzil and implications for land conservation. J. Soils Sediments. DOI 10.1007/s11368-015-1160-0

Dumitriu, D., 2014, Source area lithological control on sediment delivery ratio in Trotus Drainage Basin (Eastern Carpathians). Geogr. Fis. Dinam. Qat., v.37, pp. 1-10. Doi 10.4461/GFDQ. 2014.37.08

Duvadi, A.K, Koirala, A., Rimala, L.N., Nepali, D., Manandhar, S.P., 2006, Annual Report, Department of Mines and Geology, v. 2, pp. 50-59.

El. Hamdouni, R., Irigaray, C., Fernandez, T., Chacon, J., and Keller, E., 2007, Assessment

of Relative Active Tectonics, Southwest Border of Sierra Nevada (Southern Spain). Geomorphology, v. 96, pp.150-173. https://doi.org/10.1016/j.geomorph.2007.08.004
Glymph, L.M., 1954, Studies of sediment yields from watersheds. Tenth General Assembly of the International Union of Geodesy and Geophysics, Rome, Italy, September 15-19, pp. 178-191.

Hadley, R.F. and Schumm, S.A., 1961, Sediment sources and drainage basin characteristics in Upper Cheyenne River Basin. United States Geological Survey, Water Supply Paper, 1531-B.

Horton, R.E., 1932, Drainage basin characteristics. Transactions, Am. Geophysical Union, v. 13, pp. 350-361.

Horton, R.E., 1945, Erosional development of streams and their drainage basins: hydrophysical approach to quantitative morphology, Bull. Geol. Soc. Amer., v. 56, pp. 175-370.

Hurtrez J.E., Lucazean F., Lave J., Avouac J.P., 1999, Investigation of the relationship between basin morphology, tectonic uplift and denudation from the study of an active fold belt in Siwalik hills (Central Nepal). J Geophys Res., v. 104, pp. 779-796.

Ichim, I., 1990, The relationship between sediment delivery ratio and stream order: a Romanian case study. Erosion, Transport and Deposition Processes. Proceeding of the Jerusalem Workshop, IAHS Publ. no. 189, pp. 79-86.

Kimura, K., 1994, Formation and deformation of river terrace in the Hetauda Dun, central Nepal; A contribution to the study of post-Siwalikan tectonics. The science reports of the Tohoku University. V. 44, no. 2, pp. 151-181. http://hdl.handle.net/10097/45214

Langbein, W.B., 1947, Topographic characteristics of drainage basins. U.S.G.S. Water Supply Paper 968C, pp. 127-157.

Leopold, L.B. and Maddock, T., 1953, The Hvdraulic Geometrv of Stream Channels and Some Physiographic Irnplications. Geol. Survey Professional Paper 252, pp. 1-57.

Mahmood, S.A., Mehmood, K., Khalid, P., Afzal, Z., Amad, |J., Tariq, B., Kauka, I.S., and Hanif, M.A., 2016, DEM based analysis of neotechtonic Hindukush (N. Pakistan). Geodynamic Res. Int. Bull., v. 3, no. 5, pp. I-XIII.

Maner, S.B, 1958, Factors affecting sediment delivery rates in the red hills physiographic area. Trans. Am. Geophys., v. 39, ppl 669-675.

Maner, S.B. and Barnes, L.H. 1953, Suggested criteria for estimating gross sheet erosion and sediment delivery rates for the blackland praries problem area in soil conservation. US Department of Agriculture Soil Conservation Service, Fort Worth, Texas. Mimeograph.

Mayer, 1986, Tectonic geomorphology of escarpments and mountain fronts, in Active tectonics: edited by R. E. Wallace, National Acad. Press, Washington, D. C., pp., $125-135$.

Melton, M. A., 1957, An analysis of relations among elements 
of climate, surface properties, and geomorphology. Of. Nav. Res. Proj. NR 389-042. Tech. Rep. 11, Columbia Univ. Ph. D. dissertation. 102p.

Miller, V.C., 1953. A quantitative geomorphic study of drainage basin characteristics in the Clinch Mountain area, Verginia and Tennessee, Of. Nav. Res. Proj. NR 389-042, Tech. Rep. 3, Columbia Univ., Ph. D. dissertation, 30p.

Ngugen, K.A. and Chen, W., 2018, Estimating sediment delivery ratio by stream slope and relief ratio. MATEC web of conferences, v. $192, \quad$ p p. $1-4$. Doi.org/10.1051/matecconf/201819202040

Pike, R.J. and Wilson, S.E., 1971, Elevation-relief ratio, hypsometric integral and geomorphic area-altitude analysis. Geol Soc Am. Bull, v. 82, pp. 1079-1084.

Renfro, G.W., 1975, Use of erosion equations and sediment delivery ratios for predicting sediment yield, in present and prospective technology for predicting sediment yield and sources. Washington, USDA, pp. 33-45.

Roehl, J.E., 1962, Sediment source areas, delivery ratios and influencing morphological factors. International Association of Hydrological Sciences Publication, v. 59, pp. 202-213.

Sah, R.B., Ulak, P.D., Gajurel, A.P., and Rimal, L.N., 1994, Lithostratigraphy of the Siwalik sediments of AmlekhganjHetauda area, Sub-Himalaya of Nepal. Himalayan Geology, v. 15, pp. 37-48.

Schelling, D., 1991, A balanced cross-section across the Central Nepal Siwalik Hills, Hetauda-Amlekhganj. Journal Faculty of Science, Hokkaido University, Series IV, v. 23, no. 1, pp. 1-9.

Schumm, S., 1954, The relation of drainage basin relief to sediment loss. IAHS Publication, v. 36, pp, 216-219.

Schumm, S., 1956, Evolution of drainage system and slopes in badlands at Perth Amboy, New Jersey. Bull. Geol. Soc. Am., v. 67, pp. 597-646.

Singh, S., 1992, Quantitative geomorphology of the drainage basin, in Readings on Remote Sensing Applications, T. S. Chouhan and K. N. Joshi, Eds., Scientific Publishers, Jodhpur, India, pp. 176-183.

Singh, O., Sarangi, A., and Sharma, M.C., 2008, Hypsometric integral estimation methods and its relevance on erosion status of north-western Lesser Himalayan Watersheds. Water Resource Management, v. 22. pp. 1545-1560.

Singh, S. and Sharma, K.D., 1994, Prediction of sediment yield from the Bandi Catchment using morphometric characteristics. Annals and Arid zone, v. 33(2), pp. 109-112.

Singh, S., Gupta, B.S, and Kaith, D.S., 1977, Multiple relationship among total basin area and geomorphic drainage network variables of drainage basins in Banas Catchment, Rajasthan. National Geographer, v. 17, pp. 143-151.

Strahler, A.N., 1952, Hypsometric (area-altitude) analysis of erosional topography. Geol. Soc. Am. Bull., v. 63, no. 11, pp. 1117-1142.

Strahler, A.N., 1957, Quantitative Analysis of watershed geomorphology. Transactions, American Geophysical Union, v. 38, no. 6, pp. 913-920.

Strahler, A.N., 1964, Section 4 II Quantitative geomorphology of drainage basins and channel networks. In: Chow, V.T. (Ed.), Handbook of Applied Hydrology. McGraw-Hill, New York, pp. 4.39-4.76.

Syangbo, D.K. and Tamrakar, N.K., 2013, Lithofacies and depositional environment of the Siwalik Group in SamariSukaura River area, Central Nepal. Bulletin of the Department of Geology, Tribhuvan University, Kathmandu, Nepal, Vol. 16, 2013, pp. 53-64. DOI:Ê

Tamrakar, N.K., Yokota, S., and Shrestha, S., 2003, Petrography of the Siwalik sandstones, Amlekhganj-Suparitar area, central Nepal Sub-Himalaya. Journal of Nepal Geological Society, v. 28, pp 41-56.

Ulak, P.D. and Nakayama, K., 1998, Lithostratigraphy and evolution of the fluvial style in the Siwalik Group in the Hetauda-Bakiya Khola area, central Nepal. Bull. Dept. Geol., v. 6, pp. 1-14.

USDA-NRCS, 1983, Sediment sources, yields, and delivery ratios. Chapter 6 in National. Engineering Handbook, Section 3, Sedimentation. U.S. Department Agriculture, U.S. Government Printing Office. Washington, D.C. Natural Resources Conservation

Service formerly Soil Conservation Service (SCS), pp. 6.2-6.19

Verstraeten, G. and Poesen, J., 2001, Factors controlling sediment yields from small intensively cultivated catchments in a temperate humid climate. Geomorphology, v. 40, pp. 123-144.

Walling, D.E., 1983, The sediment delivery problem. Journal of Hydrology, v. 65, pp. 209-237.

Wasson, R.J., 1994, Annual and decadal variation in sediment yield in Australia, and some global comparisons. International Association of Hydrological Sciences Publication, v. 224, pp. 269-279. 
